\title{
Reverse Signaling via a Glycosyl-Phosphatidylinositol- Linked Ephrin Prevents Midline Crossing by Migratory Neurons during Embryonic Development in Manduca
}

\author{
Thomas M. Coate, ${ }^{1}$ Jacqueline A. Wirz, ${ }^{2}$ and Philip F. Copenhaver ${ }^{1}$ \\ Departments of ${ }^{1}$ Cell and Developmental Biology and ${ }^{2}$ Biochemistry and Molecular Biology, Program in Molecular and Cellular Biosciences, Oregon Health \\ \& Science University, Portland, Oregon 97239
}

\begin{abstract}
We have investigated whether reverse signaling via a glycosyl-phosphatidylinositol (GPI)-linked ephrin controls the behavior of migratory neurons in vivo. During the formation of the enteric nervous system (ENS) in the moth Manduca, $\sim 300$ neurons [enteric plexus (EP) cells] migrate onto the midgut via bilaterally paired muscle bands but avoid adjacent midline regions. As they migrate, the EP cells express a single ephrin ligand (MsEphrin; a GPI-linked ligand), whereas the midline cells express the corresponding Eph receptor (MsEph). Blocking endogenous MsEphrin-MsEph receptor interactions in cultured embryos resulted in aberrant midline crossing by the neurons and their processes. In contrast, activating endogenous MsEphrin on the EP cells with dimeric MsEph-Fc constructs inhibited their migration and outgrowth, supporting a role for MsEphrin-dependent reverse signaling in this system. In short-term cultures, blocking endogenous MsEph receptors allowed filopodia from the growth cones of the neurons to invade the midline, whereas activating neuronal MsEphrin led to filopodial retraction. MsEphrin-dependent signaling may therefore guide the migratory enteric neurons by restricting the orientation of their leading processes. Knocking down MsEphrin expression in the EP cells with morpholino antisense oligonucleotides also induced aberrant midline crossing, consistent with the effects of blocking endogenous MsEphrin-MsEph interactions. Unexpectedly, this treatment enhanced the overall extent of migration, indicating that MsEphrin-dependent signaling may also modulate the general motility of the EP cells. These results demonstrate that MsEphrin-MsEph receptor interactions normally prevent midline crossing by migratory neurons within the developing ENS, an effect that is most likely mediated by reverse signaling through this GPI-linked ephrin ligand.
\end{abstract}

Key words: MsEph; MsEphrin; enteric; ENS; repulsion; migration; filopodia

\begin{abstract}
Introduction
The formation of the nervous system in many organisms requires the precise migration of neurons along pathways that are delineated by a combination of stimulatory and inhibitory guidance cues. The Eph family of receptor tyrosine kinases and their ephrin ligands comprise a large group of membrane-associated proteins that can elicit either attractive or repulsive responses, depending on the developmental context (Wilkinson, 2001; Pasquale, 2005). Originally discovered for their role in establishing topographic projections within the retinotectal system (Cheng et al., 1995; Drescher et al., 1995), ephrin-Eph interactions have been shown
\end{abstract}

Received Dec. 21, 2007; revised Feb. 12, 2008; accepted Feb. 26, 2008

This work was supported by National Institutes of Health (NIH) Grant AG025525 to P.F.C. and by NIH Training Grant T32 HD049309 to T.M.C. We thank Drs. Doris Kretzschmar and David Morton for their critical input on this manuscript. We are grateful to Drs. Michael Greenberg, Zak Wills, and Shannon Robichaud (Children's Hospital and Harvard Medical School, Boston, MA) for generously providing their EphB2-specific antibodies and peptides. We also thank Drs. Ujwal Shinde and Hans-Peter Bächinger at Oregon Health \& Science University for their assistance with the biophysical characterization of our fusion proteins. Last, we thank Ms. Tracy Swanson and Mr. Todd Vogt for their many helpful discussions relating to this work.

Correspondence should be addressed to Dr. Philip F. Copenhaver, Department of Cell and Developmental Biology, L-215, Oregon Health \& Science University, 3181 Southwest Sam Jackson Park Road, Portland, OR 97239. E-mail: copenhav@ohsu.edu.

DOI:10.1523/JNEUROSCI.5691-07.2008

Copyright $\odot 2008$ Society for Neuroscience $\quad 0270-6474 / 08 / 283846-15 \$ 15.00 / 0$ to define spatial gradients and discrete boundaries in many regions of the nervous system and other tissues (Dearborn et al., 2002; Pasquale, 2005; Mohamed and Chin-Sang, 2006). In vertebrates, 16 different Eph receptors can be grouped by their ligand specificities: EphA receptors preferentially bind glycosylphosphatidylinositol (GPI)-linked (type-A) ephrins, whereas EphB receptors preferentially bind transmembrane (type-B) ephrins (Kullander and Klein, 2002; Pasquale, 2005). Conventional activation of Eph receptors by ephrin ligands ("forward" signaling) is well established, but Eph receptors can also promote "reverse" signaling by stimulating ephrin-dependent responses (Kullander and Klein, 2002; Murai and Pasquale, 2003; Davy and Soriano, 2005). Reverse signaling through type-B ephrins is often mediated by Src family kinases (SFKs), although SFKindependent signaling has also been described previously (Cowan and Henkemeyer, 2001; Wilkinson, 2001; Segura et al., 2007). Reverse signaling through type-A ephrins may similarly involve SFKs or other kinases, albeit via mechanisms that are less well understood (Knoll and Drescher, 2002; Davy and Soriano, 2005; Holmberg et al., 2005).

However, deciphering the role of particular ephrin-Eph interactions in vertebrates has been complicated by overlapping expression patterns of multiple ligands and receptors in many tis- 
sues, and by promiscuous interactions among different ligandreceptor combinations (Takemoto et al., 2002; Himanen et al., 2004; Poliakov et al., 2004). In contrast, insects typically express only a single ephrin isoform and one Eph receptor (Bossing and Brand, 2002; Dearborn et al., 2002; Kaneko and Nighorn, 2003; Vidovic et al., 2007). In the tobacco hornworm, Manduca sexta, the sole ephrin ligand (MsEphrin) is a GPI-linked protein that interacts with its receptor (MsEph) in a variety of contexts. In the antennal lobe, complementary distributions of MsEphrin and MsEph receptors promote axonal sorting to olfactory glomeruli (Kaneko and Nighorn, 2003), whereas in the enteric nervous system (ENS), their patterns of expression suggest a role in regulating neuronal migration (Coate et al., 2007). During ENS development in Manduca, 300 neurons [enteric plexus (EP) cells] must migrate onto the midgut along pre-formed muscle bands without crossing the enteric midline (Copenhaver and Taghert, 1989a; Copenhaver, 2007). MsEphrin is expressed by the neurons and their leading processes, whereas MsEph receptors are restricted to midline cells (Coate et al., 2007). Using a variety of methods to manipulate endogenous MsEphrin-MsEph interactions in cultured embryos, we have now shown that midline MsEph receptors establish a repulsive molecular boundary that prevents the MsEphrin-expressing EP cells from crossing these regions. In addition, we present evidence that reverse signaling via this GPI-linked ligand regulates neuronal guidance in the developing ENS.

\section{Materials and Methods}

Animals and whole-mount immunohistochemistry. Synchronized groups of Manduca sexta embryos were collected from an in-house breeding colony and staged according to tables of internal and external developmental markers (at $25^{\circ} \mathrm{C}, 1 \mathrm{~h}=1 \%$ of development). Dissections were performed in defined saline, as described previously (in mM: $140 \mathrm{NaCl}, 5$ $\mathrm{KCl}, 28$ glucose, $40 \mathrm{CaCl}_{2}$, and 5 HEPES, $\mathrm{pH}$ 7.4) (Horgan and Copenhaver, 1998; Coate et al., 2007). Unless otherwise indicated, chemicals were purchased from Sigma (St. Louis, MO). For all primary antibodies except anti-MsEphrin, embryos were fixed for $1 \mathrm{~h}$ in $4 \%$ paraformaldehyde (Electron Microscopy Sciences, Hatfield, PA) in PBS, pH 7.4. After rinsing in PBS, preparations were incubated in blocking solution (PBS plus $0.6 \%$ Triton $\mathrm{X}-100,10 \%$ normal serum, and $0.1 \%$ sodium azide), and primary antibodies (also diluted in blocking solution) were applied for $2 \mathrm{~h}$ at room temperature (RT) or overnight at $4^{\circ} \mathrm{C}$. Antibodies were used in the following concentrations: anti-pan-MsFas II, 1:20,000 [monoclonal C3, against the extracellular domain of Manduca fasciclin II (MsFas II)] (Wright et al., 1999); anti-transmembrane MsFas II, 1:1000 (TM-MsFas II) (Wright and Copenhaver, 2000); goat anti-Fc, 1:200 (Jackson ImmunoResearch, West Grove, PA); and goat-anti-Fluorescein isothiocyanate, 1:100 (Jackson ImmunoResearch). As an additional marker for the enteric midline cells (independent of MsEph), we also immunostained preparations with the monoclonal antibody 4E11 (1: 20). This antibody was originally isolated from a panel of antibodies generated against the developing ENS, and recognizes a partially characterized $112 \mathrm{kDa}$ glycoprotein that is selectively expressed by the middorsal and midventral muscle cells of the midgut (L. Kaler and P. F. Copenhaver, unpublished data). After incubation with primary antibodies, preparations were rinsed for $2 \mathrm{~h}$ and incubated with fluorochromeconjugated secondary antibodies for $1-2 \mathrm{~h}$ at RT or overnight at $4^{\circ} \mathrm{C}$, then rinsed and mounted in SlowFade Gold (Invitrogen, Eugene, OR). Alexa Fluor-conjugated secondary antibodies $(1: 1000)$ were obtained from Invitrogen; Cy3-conjugated secondaries (1:400) were from Jackson ImmunoResearch. For anti-MsEphrin immunostaining, unfixed embryos were incubated for $90 \mathrm{~min}$ in chicken anti-MsEphrin (1:100) (following Coate et al., 2007), then rinsed extensively before fixation with $4 \%$ paraformaldehyde for $1 \mathrm{~h}$. The preparations were then incubated with additional primary and secondary antibodies, as described above.

Previously, we developed an anti-peptide antiserum against the
MsEph receptor, which revealed that midline interband cells of the midgut are the only cells associated with the developing ENS that express MsEph (Coate et al., 2007). However, because this antiserum proved unsuitable for triple immunolabeling experiments (described below), we used an affinity-purified antibody that recognizes an evolutionarily conserved epitope shared by vertebrate EphB2 and MsEph (generously provided by Dr. M. E. Greenberg and colleagues, Children's Hospital and Harvard Medical School, Boston, MA) at 1:200 (Dalva et al., 2000). As with our original anti-MsEph antiserum, the anti-EphB2 antibody labeled only the midline interband cells in the developing ENS (supplemental Fig. $1 A$, available at www.jneurosci.org as supplemental material). The specificity of this antibody for MsEph in Manduca was verified by preadsorbing an aliquot of the antibody against its peptide epitope (also provided by Dr. Greenberg), at a 10:1 molar ratio (peptide:antibody) for $4 \mathrm{~h}$ at RT. This pretreatment eliminated all immunoreactive staining in Manduca embryos (supplemental Fig. $1 B$, available at www. jneurosci.org as supplemental material). In immunoblots of pupal brain lysates (stage P3), the anti-EphB2 antibody labeled a single $\sim 115 \mathrm{kDa}$ band, corresponding to the predicted size of endogenous MsEph (112 $\mathrm{kDa}$ ) (supplemental Fig. 1C, lane 1, available at www.jneurosci.org as supplemental material); this band was also eliminated by preadsorption of the antibody against its peptide epitope (supplemental Fig. 1C, lane 2, available at www.jneurosci.org as supplemental material). Similar controls for our anti-MsEphrin and MsFas II antibodies have been documented previously (Wright and Copenhaver, 2000; Coate et al., 2007).

Fusion protein preparation and in vivo binding assays. MsEphrin-Fc and MsEph-Fc fusion proteins were generated as described previously (Kaneko and Nighorn, 2003; Coate et al., 2007) and used to target endogenous MsEphrin or MsEph receptors in cultured embryos. To generate MsEphrin-6His and MsEph-6His fusion proteins, 293-EBNA (Epstein-Barr virus nuclear antigen) cells were stably transfected with the pCEP4 expression vector (Invitrogen) containing the sequence for the extracellular domain of either MsEphrin or MsEph, in-frame with a C-terminal $6 \times$ histidine tag ( $6 \mathrm{His}$ ). Stable cell lines expressing the fusion proteins were maintained in standard growth medium (DMEM; 10\% fetal bovine serum) plus $250 \mu \mathrm{g} / \mathrm{ml} \mathrm{G418}$ and $300 \mu \mathrm{g} / \mathrm{ml}$ hygromycin B; protein expression levels were monitored in immunoblots using an anti6 His monoclonal antibody (1:5000; Clontech, Mountain View, CA). After sufficient expansion of the cultures, the growth medium was replaced with Opti-MEM (Invitrogen) for an additional $7 \mathrm{~d}$. Secreted 6His-tagged proteins were then purified and concentrated from the medium with cobalt-conjugated Sepharose beads, using Talon resin from Clontech or His-Select Cobalt Affinity resin from Sigma; both resins provided equivalent yields.

Analysis of fusion protein dimerization/oligomerization. Twenty nanograms of each Fc- and 6His-tagged fusion protein were diluted in Laemmli buffer (Laemmli, 1970) with or without $\beta$-mercaptoethanol ( $\beta \mathrm{ME}$; $5 \%$ ), then separated on $4-12 \%$ gradient gels (Criterion; Bio-Rad, Hercules, CA) and transferred to nitrocellulose membranes. The immunoblots were then labeled with either anti-Fc or anti-6His antibodies to determine the relative abundance of monomers versus dimers and oligomers in the samples, based on their predicted sizes. Alternatively, concentrated samples of each fusion protein were subjected to analytical ultracentrifugation, following published methods (Frank et al., 2001; Kobayashi et al., 2007). Briefly, each protein sample was dialyzed against PBS, pH 7.4, plus $150 \mathrm{~mm} \mathrm{NaCl}$ and concentrated to $0.3-0.5 \mathrm{mg} / \mathrm{ml}$. Sedimentation equilibrium measurements were performed in double sector cells on a Beckman Coulter (Fullerton, CA) XLA analytical ultracentrifuge at 4 or $20^{\circ} \mathrm{C}$, using a rotor speed of $15,000 \mathrm{rpm}$. Concentrations were monitored at $230 \mathrm{~nm}$ as a function of radial distance to determine molecular masses (van Holde, 1985); data were analyzed by nonlinear least squares fitting (Scientist; Micromath, St. Louis, MO).

In vivo manipulations of cultured embryos. Staged embryos were isolated before the onset of EP cell migration (at $52-53 \%$ of development) in a customized culture medium (Wright et al., 1999). Embryos were restrained in Sylgard-coated chambers, and the developing ENS was exposed by a small incision in the dorsal body wall. The ENS was then treated with either control culture medium or medium containing one of our epitope-tagged fusion proteins (at $0.1-100 \mu \mathrm{g} / \mathrm{ml}$ ). Similar concen- 
trations of human Fc (Jackson ImmunoResearch) were used as an additional control. For some experiments, Fc proteins were preclustered for 30 min with anti-human Fc antibodies (Jackson ImmunoResearch) at a 5:1 molar ratio of antibody:Fc protein (following Davis et al., 1994; Kaneko and Nighorn, 2003). After application of the fusion proteins, embryos were cultured at $28^{\circ} \mathrm{C}$ for $24 \mathrm{~h}$ (through the period of EP cell migration and axon outgrowth). At the end of each experiment, the preparations were re-dissected to expose the ENS and immunostained with anti-MsFas II, using the ABC HRP kit from Vector Laboratories (Burlingame, CA). This procedure allowed the EP cells and their processes to be visualized unambiguously (Horgan et al., 1995; Wright and Copenhaver, 2000; Coate et al., 2007). The extent of EP cell migration, axon outgrowth, and number of midline crossover events was then analyzed using photomicrographic and camera lucida techniques (Wright et al., 1999; Wright and Copenhaver, 2000). Statistical analyses were performed using Student's two-tailed $t$ test to compare means. Because the frequency of crossover events best fit a Poisson distribution, the Wilcox Signed Rank test was used to calculate significant differences between cumulative frequencies in the different groups. Each experiment was performed at least three times.

Filopodial orientation assays. Embryos were opened in culture at $60 \%$ of development (when the EP cells transition from migration to axon outgrowth), and treated with control Fc, MsEph-Fc, or MsEphrin-Fc proteins at $20 \mu \mathrm{g} / \mathrm{ml}$ in defined saline (Horgan and Copenhaver, 1998). This concentration was chosen because of its intermediate effects on EP cell migration and outgrowth in overnight cultures (described below), and because similar concentrations of ephrin- and Eph-Fc fusion proteins have produced physiological responses in other culture systems (St. John et al., 2000; Santiago and Erickson, 2002; Fu et al., 2007). After the application of our Fc constructs, the preparations were allowed to develop for another $4 \mathrm{~h}$ at RT, then fixed and immunostained with antiTM-MsFas II to visualize the leading growth cones and associated filopodia of the EP cells. The preparations were also counterstained with 4E11 to visualize the midline muscle cells. Confocal $z$-stack images of the preparations were then analyzed to determine the percentage of EP cell filopodia that had extended onto the inhibitory midline regions versus the normal muscle band pathways. Growth cone areas were calculated by outlining each growth cone [using Adobe (San Jose, CA) Photoshop], followed by quantification of the profiles with ImageJ (http://rsb. info.nih.gov/ij/). At least 12 preparations were used for each condition; statistical differences between experimental groups were determined using Student's two-tailed $t$ test to compare means.

Morpholino experiments. Morpholino antisense oligonucleotides (morpholinos; Gene Tools, Philomath, OR) were designed against the 5' UTR sequence flanking the initiation codon of the MsEphrin gene ( $5^{\prime}$ CATAATAAAACTAACACTGCGACAC). Morpholinos $(1-50 \mu \mathrm{M})$ were diluted in defined saline (supplemented with $10 \%$ heat-inactivated normal horse serum, $0.5 \%$ penicillin/streptomycin, $0.2 \%$ ecdysone, $0.1 \%$ insulin and $0.2 \mathrm{M} \mathrm{L}$-glutamine) and transfected into the EP cells of cultured embryos with $0.6 \%$ Endo-Porter (Gene Tools) (after Summerton, 2005). This range of morpholino concentrations was based on their effectiveness in knocking down endogenous MsEphrin expression in Manduca GV-1 cell cultures (our unpublished data). Matched sets of embryos were transfected with $3^{\prime}$ carboxyfluorescein (CFSE)-labeled control morpholinos (Gene Tools) or treated with Endo-Porter alone. To optimize the effectiveness of this protocol, embryos were treated with morpholinos starting at $45 \%$ of development $( \pm 1 \%)$ and then allowed to develop for another $48 \mathrm{~h}$ at $28^{\circ} \mathrm{C}$. At the end of each experiment, the preparations were double-immunostained with anti-MsEphrin (visualized with Cy3-conjugated secondary antibodies) and anti-MsFas II (visualized with Alexa 488 conjugated secondary antibodies), as described above. To quantify the relative expression levels of both MsFas II (as an off-target control) and MsEphrin in the same EP cells, a $2 \mu \mathrm{m} z$-stack image (consisting of four sequential $0.5 \mu \mathrm{m}$ confocal sections) was taken from the leading groups of neurons in each preparation; a second set of matched optical sections was taken from their fasciculated axons. Each 2 $\mu \mathrm{m}$ stack was then compressed, and fluorescent intensities within regions of interest were quantified using ImageJ software. Background fluorescence levels in each preparation were determined from identical $z$-stack images that were collected from adjacent interband muscle regions (areas that were devoid of endogenous MsFas II and MsEphrin expression). The ratios of EP cell-associated fluorescence versus background fluorescence levels were then used to normalize the relative intensities of each fluorochrome in the neurons and their processes; these normalized values were then used to compare relative levels of MsEphrin and MsFas II expression (analyzed independently) between groups. At least 14 preparations were analyzed for each treatment condition, and Student's two-tailed $t$ tests were used to compare means for statistical significance. All measurements were performed under linear parameters. Once this analyses was complete, the preparations were re-stained with anti-MsFas II antibodies and the ABC HRP protocol (Vector Laboratories) to quantify the extent of EP cell migration, axon outgrowth, and number of midline crossover events (as described above).

\section{Results \\ MsEph and MsEphrin are expressed in complementary domains}

As described previously (Copenhaver and Taghert, 1989a,b; Copenhaver, 2007), the formation of the ENS in Manduca requires the precise migration of enteric neurons (EP cells) from the foregut onto the midgut, before their innervation of the visceral musculature (Fig. 1). After delaminating from a neurogenic placode in the foregut ectoderm (Copenhaver and Taghert, 1990), the EP cells spread bilaterally around the foregut along the foregut-midgut boundary (from 40 to $55 \%$ of development). By $55 \%$ of development, subsets of these neurons (Fig. $1 A$, red) align with one of eight longitudinal muscle bands (green) that have recently coalesced on the adjacent midgut surface, forming a set of functionally equivalent pathways. Over the next $10 \mathrm{~h}$ (from 55 to $65 \%$ of development) (Fig. $1 B, C$ ), the neurons migrate rapidly along the muscle bands onto the midgut, followed by a more prolonged period of axon outgrowth along the bands (from 65 to $80 \%)$. Although each EP cell extends an array of exploratory filopodia in advance of its leading process, the neurons and their axons remain closely associated with the muscle band pathways, while avoiding the adjacent midline muscle cells (Fig. $1 A-C$, blue) and lateral interband regions. Only after migration and axon outgrowth is complete ( $\sim 80 \%$ of development) do the neurons extend terminal branches laterally, providing a diffuse innervation of the midgut musculature (Copenhaver and Taghert, 1989b; Wright et al., 1998).

Previous studies showed that the guidance of the EP cells along the midgut bands is regulated in part by the adhesion receptor MsFas II, an Ig-family receptor that is the ortholog of NCAM (neural cell adhesion molecule) and OCAM (olfactory cell adhesion molecule) in vertebrates (Grenningloh et al., 1991; Hamlin et al., 2004). MsFas II is simultaneously expressed by both the neurons and the muscle band cells during this period (Fig. $1 E, H, K$ ), and manipulations in embryo culture have shown that homophilic interactions between MsFas II on the neurons and muscle bands promote migration and outgrowth along these pathways (Wright et al., 1999; Wright and Copenhaver, 2000). In contrast, the expression patterns of MsEph and MsEphrin in the developing ENS suggest that they regulate the behavior of the EP cells at the midline. MsEphrin is expressed only by the migrating neurons and their leading processes (Fig. $1 D-L$, red), whereas MsEph is expressed by midline muscle cells on the dorsal and ventral surfaces of the gut (Fig. 1D-L, blue cells) (Coate et al., 2007). At higher magnification, MsEphrin-positive filopodia from the EP cells (Fig. 1G-I, arrows) and their growth cones (Fig. $1 J-L$, arrows) can be seen extending across the surface of the MsFas II-positive muscle bands ("b") and up to the midline cells (which express the MsEph receptor; asterisks), but only rarely do 

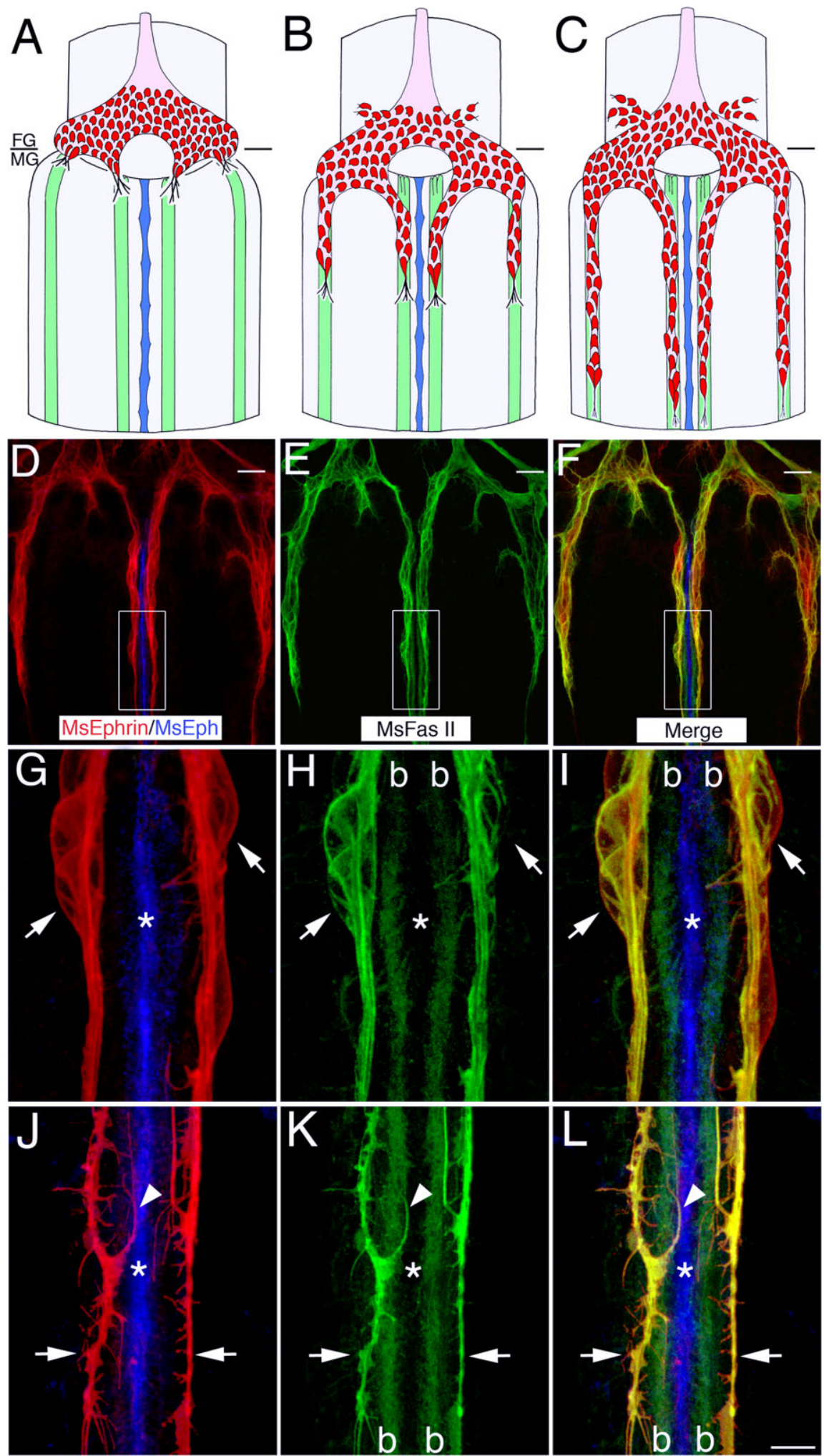

Figure 1. MsEphrin and MsEph are expressed in complementary patterns within the developing ENS. A-C, Schematic representation of the migration pattern of neurons that form the enteric plexus ( $E P$ cells; red). $A, B y \sim 55 \%$ of development, all of the EP cells express MsEphrin, and subsets of the neurons have begun to align with each of eight muscle band pathways (green), which express MsFas II (the EP cells also express MsFas II; not illustrated in $\boldsymbol{A}-\boldsymbol{C}$ ). Only the four dorsal muscle bands are shown. $\boldsymbol{B}$, At $\sim 60 \%$ of development, the EP cells migrate posteriorly along the muscle bands while avoiding the midline muscles (blue), which express MsEph.C, At $\sim 65 \%$ of development, the EP cells have completed migration, but they continue to extend axonal processes along the band pathways while avoiding the midline. FG/MG, The foregut-midgut boundary. $\boldsymbol{D}$, Confocal micrograph of a $65 \%$ embryo stained with antibodies against MsEphrin (labeling the neurons; red) and MsEph (labeling the midline; blue). $\boldsymbol{E}$, Same preparation counterstained with anti-MsFas II (labeling both the neurons and the muscle bands; green). $\boldsymbol{F}$, Merged view of $\boldsymbol{D}$ and E. G-I, Enlarged views of the boxed areas in D-F. G, MsEphrin antibodies (red) label the EP cell somata (arrows) and leading they extend onto these midline regions, suggesting that they stall or turn away from the midline cells after contacting them (Fig. 1J-L, arrowhead) (Copenhaver, 2007). Thus, MsEphrin ligands and MsEph receptors are expressed in strictly complementary domains within the developing ENS.

Blocking endogenous MsEph-MsEphrin interactions induces aberrant

midline crossing

Based on the foregoing patterns of expression, we proposed that repulsive interactions mediated by MsEphrin on the EP cells and MsEph receptors on the midline cells prevent the neurons from crossing the gut midline. To test this hypothesis, we generated affinity-purified MsEphrin-Fc fusion proteins designed to target endogenous MsEph receptors within the ENS. When analyzed in Western blots run under reducing conditions, MsEphrin-Fc behaved as a monomer with an apparent mass of $\sim 55 \mathrm{kDa}$ (Fig. 2, lane 1), as predicted from its primary amino acid sequence. In contrast, under nonreducing conditions, the protein migrated with the apparent size of a dimer $(\sim 110 \mathrm{kDa})$ (Fig. 2 , lane 2). Likewise, when we examined the molecular mass of MsEphrin-Fc in physiological saline by analytical ultracentrifugation, the protein was detected primarily as a dimer $(\sim 130 \mathrm{kDa})$ (data not shown). These results are consistent with current models of Ephrins and Eph receptors in other systems, which predict that both the ligands and receptors initially form dimers and then interact with a 2:2 stoichiometry (Fig. 3A) (Himanen et al., 2001; Chrencik et al., 2006; Pabbisetty et al., 2007).

Previously, we showed that Fc fusion proteins can be used to detect bioavailable pools of MsEphrin and MsEph receptors within the developing ENS (Coate et al., 2007). When we applied MsEphrin-Fc to the ENS of cultured embryos, we found

\footnotetext{
processes, whereas MsEph antibodies (blue) label the midline cells (asterisk). $\boldsymbol{H}$, MsFas II antibodies (green) label both the neurons (arrows) and muscle bands (b) but not the midline cells (asterisk). $\boldsymbol{I}$, Merged view of $\boldsymbol{G}$ and $\boldsymbol{H}$; the EP cells migrate and extend axons along the muscle bands (green), but not across the midline cells (blue). $J-L$, Distal processes extended by the EP cells at a more posterior position on the midgut (not visible in $\mathbf{D}-\boldsymbol{I}$ ). J, MsEphrin antibodies (red) label the growth cones and filopodia of the EP cells that have grown along the band pathways; MsEphrin-positive filopodia (arrowhead) typically extend up to but not across the midline cells (asterisk), which express MsEph (blue). $\boldsymbol{K}$, MsFas II antibodies label both the EP cell processes and the muscle band pathways (b), but not the midline cells (asterisk). $\boldsymbol{L}$, Merged view of $\boldsymbol{J}$ and $\boldsymbol{K}$. Scale bars: $\boldsymbol{A}-\boldsymbol{F}, 50 \mu \mathrm{m}$; (in $\boldsymbol{L}) \mathbf{G}-\boldsymbol{L}, 7 \mu \mathrm{m}$.
} 


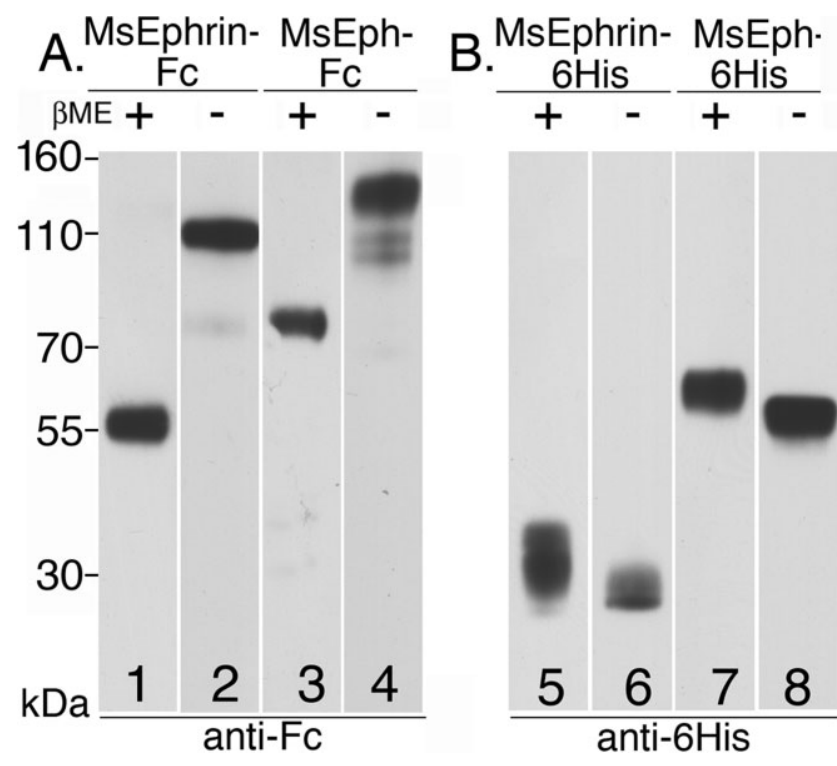

Figure 2. $\quad \boldsymbol{A}, \boldsymbol{B}$, Immunoblot analysis of $\mathrm{Fc}$ - and 6 His-tagged fusion proteins. Lanes $1-2$, MsEphrin- $\mathrm{Fc}(20 \mathrm{ng})$ was electrophoresed under reducing conditions (+ $\beta \mathrm{ME}$; lane 1) or nonreducing conditions ( $-\beta \mathrm{ME}$; lane 2 ) and detected with anti- $\mathrm{Fc}$ antibodies. Under reducing conditions, MsEphrin-Fc migrated with the apparent molecular size of $\sim 55 \mathrm{kDa}$, equivalent to the predicted size of the monomeric protein, whereas under nonreducing conditions, the protein migrated primarily as a dimer ( $~ 110 \mathrm{kDa})$. Lanes 3-4, MsEph-Fc (20 ng) was electrophoresed under reducing conditions ( $+\beta \mathrm{ME}$; lane 3 ) or nonreducing conditions ( $-\beta \mathrm{ME}$; lane 4$)$ and detected with anti-Fc antibodies. Under reducing conditions, MsEph-Fc migrated with the apparent molecular size of $\sim 86 \mathrm{kDa}$, equivalent to the predicted size of the monomeric protein, whereas under nonreducing conditions the protein migrated primarily as a dimer $(\sim 150 \mathrm{kDa})$. Lanes 5-6, MsEphrin-6His (20 ng) was electrophoresed under reducing conditions (+ $\beta \mathrm{ME}$; lane 5) or nonreducing conditions ( $-\beta \mathrm{ME}$; lane 6 ) and detected with anti-6His antibodies. MsEphrin-6His migrated primarily as a monomer under both conditions (predicted size, 28 $\mathrm{kDa}$ ). Lanes 7-8, MsEph-6His (20 ng) was electrophoresed under reducing conditions ( $+\beta \mathrm{ME}$; lane 7) or nonreducing conditions ( $-\beta M E$; lane 8 ) and detected with anti-6His antibodies. MsEph-6His migrated primarily as a monomer under both conditions (predicted size, $62 \mathrm{kDa}$ ); the slightly smaller apparent size seen under nonreducing conditions may reflect incomplete denaturation of the protein.

that it selectively bound the midline muscle cells of the midgut (Fig. $3 B, C$ ), a pattern that precisely corresponded with the endogenous expression of MsEph receptors by these cells (Fig. 1). We then tested whether applying MsEphrin-Fc to the ENS at the onset of EP cell migration (targeting MsEph receptors at the midline) affected the subsequent behavior of the neurons and their processes. As shown in Figure 3, this treatment caused a substantial number of EP cells to migrate and extend neurites abnormally across the midline (Fig. $3 E, F$, asterisks indicate the mid-dorsal midline cells in each panel). Similar pathfinding errors were seen in their axonal trajectories, resulting in the deviation of both fasciculated axon bundles (Fig. $3 H$ ) and what appeared to be individual branches (Fig. 3I) across the midline (based on previous neuroanatomical observations of individual EP cells; Copenhaver and Taghert, 1989a,b). In contrast, embryos treated with normal medium or with control Fc proteins did not exhibit these types of crossover errors by either the EP cells (Fig. 3D) or their axons (Fig. 3G), which remained confined to their normal band pathways. Quantification of the number of crossover events per embryo in these experiments (Fig. 4A) showed that control Fc proteins caused no significant effects at concentrations as high as $100 \mu \mathrm{g} / \mathrm{ml}$; as in untreated control embryos (histogram C), these preparations exhibited only rare instances of neurites that strayed across the midline. In contrast, treatment with MsEphrin-Fc (from $0.1-50 \mu \mathrm{g} / \mathrm{ml}$ ) caused a concentration-dependent increase in crossover events: at $0.1 \mu \mathrm{g} / \mathrm{ml}$, MsEphrin-Fc induced more than twice the average number of crossover events (compared with control Fc proteins), whereas treatments with $50 \mu \mathrm{g} / \mathrm{ml}$ induced a maximal sixfold increase in the number of cells and processes that deviated across the midline (Fig. $4 \mathrm{~A}$ ). Similar concentrations of ephrin- and Eph-Fc fusion proteins have been shown to induce physiological responses in a variety of other culture assays (Santiago and Erickson, 2002; Kasemeier-Kulesa et al., 2006; Fu et al., 2007; Vidovic et al., 2007), whereas higher concentrations did not produce significantly more crossover events in the developing ENS (data not shown). Despite these defects, MsEphrin-Fc treatments did not significantly affect the overall extent of EP cell migration or axonal outgrowth along the normal muscle band pathways (Fig. $4 B, C$ ), nor did they cause any other obvious abnormalities in ENS development. These results suggest that interactions between MsEphrin on the EP cells and MsEph receptors on the midline muscles of the gut normally prevent inappropriate midline crossing by the neurons, but they do not apparently play a predominant role in regulating other aspects of neuronal migration and outgrowth.

Manipulations designed to precluster ephrin-Fc and Eph-Fc fusion proteins have often been found to potentiate the activation of their cognate binding partners in cell culture (Davis et al., 1994; Hattori et al., 2000; Palmer and Klein, 2003). However, preclustering MsEphrin-Fc with anti-Fc antibodies caused only a slight increase in the frequency of crossover events that was not significantly different from the effects of unclustered proteins at the same concentrations (Fig. $4 A$; compare $\pm \operatorname{IgG}$ ). Given our evidence that MsEphrin-Fc spontaneously forms dimers but not multimers under physiological conditions (Fig. 2) (data not shown), these results indicate that higher order complexes of MsEphrin were not required for the effects seen in this in vivo context.

Previous studies have indicated that ephrin-Fc dimers may either block endogenous ligand-receptor interactions (thereby preventing signal transduction) or activate Eph receptors (inducing "forward" signaling) (Krull et al., 1997; Stein et al., 1998; Contractor et al., 2002). To determine whether MsEphrin-Fc treatments induced midline crossing in the ENS by blocking endogenous MsEphrin-MsEph interactions or by over-stimulating MsEph receptor activation, we generated monomeric MsEphrin6 His fusion proteins that, based on current models, should bind but not activate MsEph receptors (cf. Davis et al., 1994). As shown in Figure 2 (lanes 5, 6), immunoblots of purified MsEphrin-6His showed that it behaved as a monomer under both reducing and nonreducing conditions (predicted size, 28 $\mathrm{kDa}$ ), in contrast to the spontaneous dimers formed by MsEphrin-Fc (Fig. 2, lane 2). Notably, treating the developing ENS with monomeric MsEphrin-6His induced abnormal midline crossing by both the migrating EP cells (Fig. $3 K$ ) and their growing processes (Fig. $3 L$ ), at frequencies that were comparable with the effects of dimeric MsEphrin-Fc (Fig. 4A). As with MsEphrin-Fc treatments, however, MsEphrin-6His did not induce significant alterations in the overall distance of migration or axonal outgrowth along the normal band pathways (Fig. $4 B, C$ ), suggesting that endogenous MsEphrin-MsEph interactions specifically regulate the behavior of the migratory neurons at the midline.

The effects of these manipulations were also apparent in camera lucida images taken from the different culture preparations. In mock-treated preparations or preparations treated with control Fc proteins (supplemental Fig. $2 B$, available at www.jneurosci.org as supplemental material), both the neurons and their axons re- 

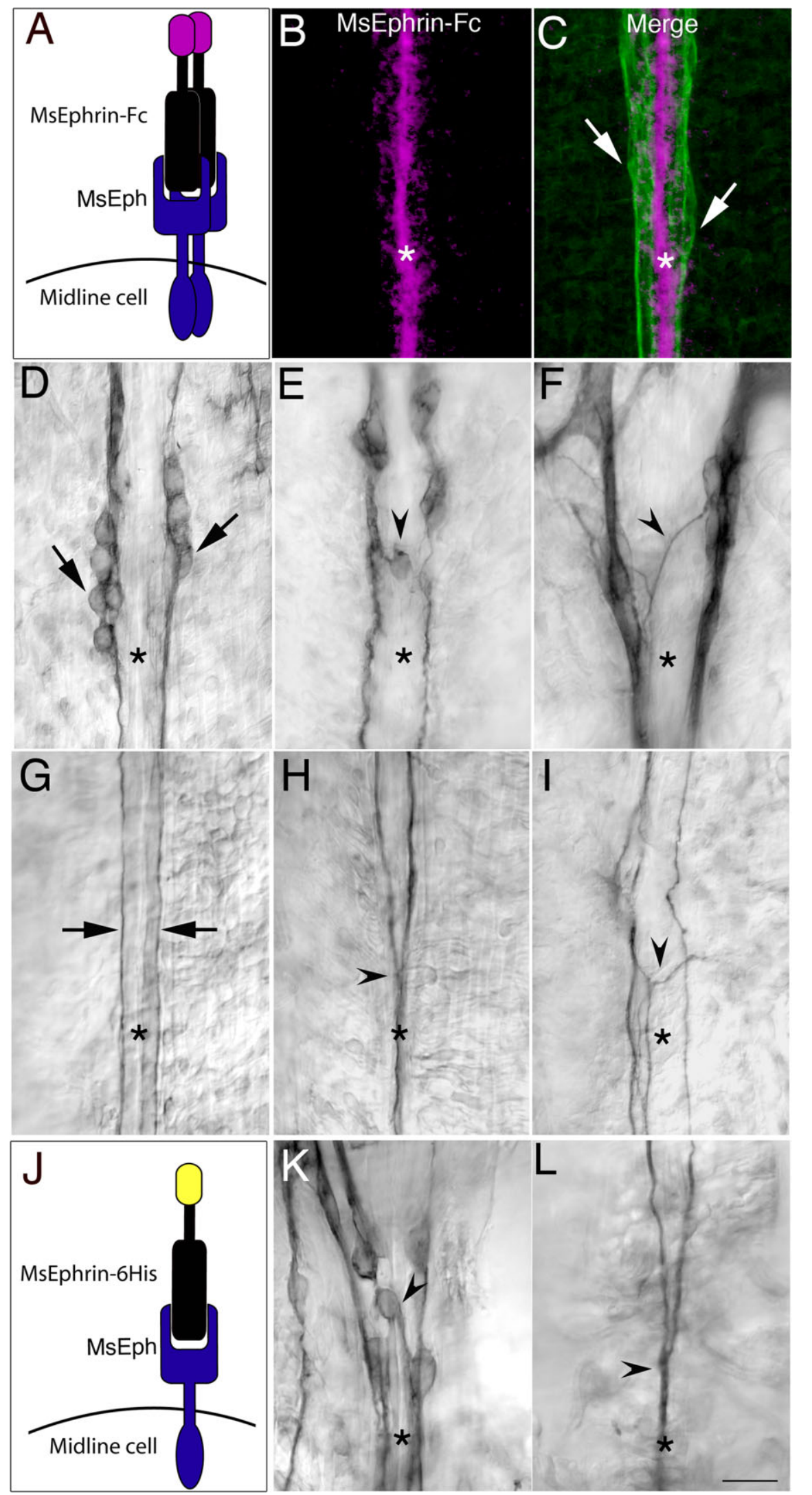

Figure 3. Treating the developing ENS with MsEphrin fusion constructs induced midline crossing by the EP cells and their processes. $A$, Schematic diagram illustrating the interaction between dimeric MsEphrin- $F$ c fusion proteins (black, with magenta $F c$ tag) and MsEph receptors on the midline cells (blue). $\boldsymbol{B}$, MsEphrin-Fc selectively binds the midline cells of the midgut (magenta; asterisk) when applied to the ENS of unfixed tissue (at $4^{\circ} \mathrm{C}$; detected with anti-Fc antibodies). C, Counterstaining the same preparation with anti-MsFas II antibodies (green) shows that MsEphrin-Fc does not label the EP cells (arrows) or the muscle band pathways. $D-I$, Embryos that were treated with $\mathrm{Fc}$ proteins for $24 \mathrm{~h}$ in culture, then immunostained with anti-MsFas II to reveal mained closely apposed to the normal muscle band pathways throughout the course of migration and outgrowth (panel $A$ illustrates the position of the premigratory EP cells at the onset of these experiments). In contrast, embryos treated with either MsEphrin-Fc (supplemental Fig. $2 C$, available at www.jneurosci.org as supplemental material) or MsEphrin-6His (data not shown) exhibited a substantial number of aberrant crossover events at the midline, although the overall extent of EP cell migration and outgrowth was unaffected. Because both monomeric MsEphrin-6His and dimeric MsEphrin-Fc induced identical crossover phenotypes without significantly altering neuronal motility, these results argue that their effects were primarily caused by interference with endogenous MsEphrin-MsEph interactions, rather than the induction of a forward signaling response through MsEph receptors on the midline cells.

\section{Activating MsEphrin ligands on the EP cells inhibits migration and axonal outgrowth}

To target endogenous MsEphrin ligands expressed by the migratory EP cells, we also generated Fc-tagged fusion constructs containing the extracellular domain of the MsEph receptor (Coate et al., 2007). As with MsEphrin-Fc, Western blots of purified MsEph-Fc showed that it migrated as monomer in reducing conditions, with the predicted molecular size of $86 \mathrm{kDa}$ (Fig. 2, lane 3). However, in Western blots run under nonreducing conditions, MsEph-Fc migrated as a dimer $(\sim 150 \mathrm{kDa})$ (lane 4$)$. When examined in solution by analytical ultracentrifugation, MsEph-Fc proteins also behaved primarily as dimers $(\sim 174$ $\mathrm{kDa}$ ), although a small percentage of the

the EP cells and their processes. $D, G$, Embryo that was treated with control $F$ c protein; the EP cells ( $\boldsymbol{D}$, arrows) and their processes ( $\boldsymbol{G}$, arrows) traveled normally along their muscle band pathways without crossing onto the midline cells (asterisk). $\boldsymbol{E}$, $\boldsymbol{F}, \boldsymbol{H}, \boldsymbol{I}$, Embryos that were treated with MsEphrin-Fc showed a variety of midline crossover phenotypes. $\boldsymbol{E}$, Example of an EP cell that migrated ectopically across the midline. $\boldsymbol{F}$, Example of an EP cell neurite that grew across the midline. $\boldsymbol{H}$, Preparation in which the distal axon fascicles of the EP cells had merged on the midline cells. $I$, Preparation in which the distal process of an EP cell defasciculated and crossed the midline.J, Schematic diagram illustrating the interaction between monomeric MsEphrin-6His fusion proteins (black, with yellow 6His tag) and MsEph receptors on the midline cells (blue). $\boldsymbol{K}, \boldsymbol{L}$, Embryos that were treated with MsEphrin-6His showed similar examples of midline crossing by the EP cells $(\boldsymbol{K})$ and distal axons $(\boldsymbol{L})$. Arrowheads in all panels indicate crossover events; asterisks indicate the midline. Scale bar, $40 \mu \mathrm{m}$ (all micrographs). 

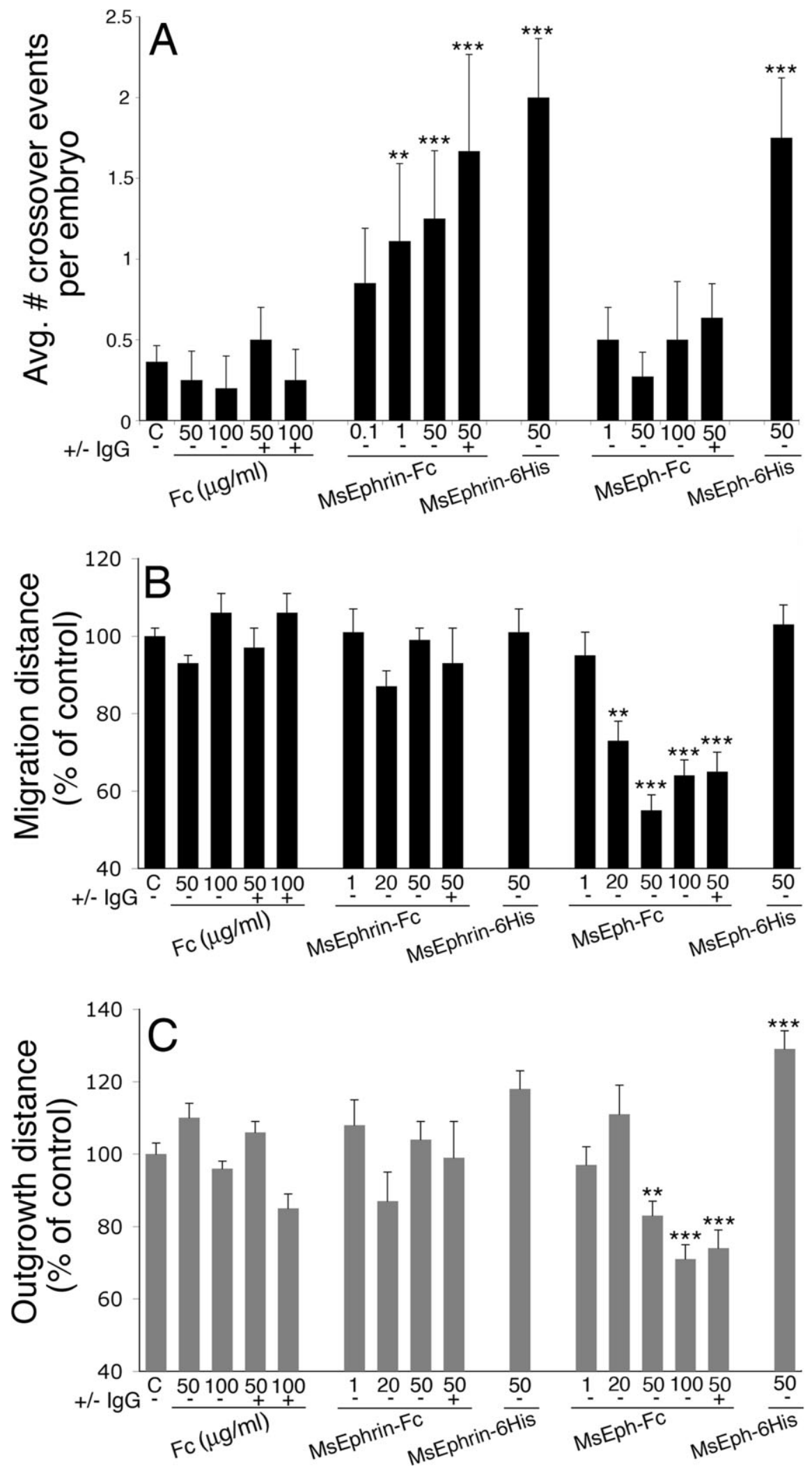

Figure 4. Quantitative analysis of the effects MsEphrin and MsEph fusion proteins on the behavior of the EP cells and their processes. $\boldsymbol{A}$, Histogram depicting the average number of crossover events per embryo (including cells, axon fascicles, and isolated neurites). Whereas crossover events were only rarely seen in untreated control preparations $(C)$ or preparations treated with control Fc protein, treatment with dimeric MsEphrin-Fc induced a concentration-dependent increase in all types of crossover events. Monomeric MsEphrin-6His and monomeric MsEph-6His proteins both induced crossover events at the same frequency as dimeric MsEphrin-Fc, whereas preclustering the Fc fusion proteins with anti-Fc antibodies ( $\pm \lg G$ ) did not induce significantly more crossover events than the unclustered proteins. In contrast, dimeric MsEph-Fc did not induce crossovers more frequently than in controls. $\boldsymbol{B}, \boldsymbol{C}$, Histograms illustrating the extent of EP cell migration and outgrowth along the muscle band pathways in total protein migrated as larger aggregates (data not shown).

Using MsEph-Fc proteins to label cultured embryos (at $4^{\circ} \mathrm{C}$ ), we found that they specifically bound to the EP cells and their processes but not the underlying muscle bands or the midline cells (Fig. $5 A-C$ ). This pattern corresponds precisely with the neuronal-specific expression of MsEphrin within the developing ENS (Coate et al., 2007). However, when we exposed the EP cells to dimeric MsEph-Fc at the onset of migration, we observed no significant increase in the frequency of midline crossing events, in marked contrast to the effects of either MsEphrin-Fc and MsEphrin-6His proteins (Fig. 4A). Instead, MsEph-Fc treatments caused a dramatic inhibition in the extent of migration and outgrowth by the neurons, without inducing aberrant sprouting onto the midline (Fig. 5E,F). EP cells in these preparations often stalled soon after leaving the foregut-midgut boundary (Fig. 5E; the foregut-midgut boundary is indicated by the paired black bars); at higher concentrations, the EP cells completely failed to migrate (Fig. 5F, supplemental Fig. 2D,E, available at www.jneurosci.org as supplemental material). The inhibitory effects of MsEph-Fc were both concentrationdependent (over a range of $1-50 \mu \mathrm{g} / \mathrm{ml}$ ) and statistically significant (Fig. $4 B, C$ ), in marked contrast to the minor changes in the overall distance of migration and outgrowth caused by either MsEphrin-Fc or MsEphrin-6His. Preclustering MsEph-Fc proteins with anti-Fc antibodies did not further enhance their potency in inhibiting neuronal migration and outgrowth (Fig. 4B,C; “ $\pm \operatorname{IgG”).~Thus,~as~with~}$ MsEphrin-Fc, the formation of higher order complexes did not appear necessary for the biological activity of MsEph-Fc in this in vivo context.

The inhibitory effect of MsEph-Fc pro-

$\leftarrow$

each treatment group (normalized to matched control preparations). Treatments with either dimeric MsEphrin-Fc or monomeric MsEphrin-6His caused no significant alterations in the distance traveled by the neurons and their processes compared with controls; treatment with monomeric MsEph-6His also did not affect migration but caused significant enhancement of axon outgrowth. In contrast, treatment with dimeric MsEph-Fc caused a concentration-dependent inhibition of both migration and outgrowth along the band pathways. The effects of preclustered MsEph-Fc ("+ cantly different from unclustered dimeric proteins at the same concentrations. Fc protein concentrations are given in micrograms pre milliliter. " $+/-\lg \mathrm{G}^{\prime \prime}$ indicates whether the $\mathrm{Fc}$ proteins were preclustered with an anti-Fc $\lg G$ before their application. Statistical analysis was performed using Student's $t$ test, ${ }^{* *} p<0.01 ;{ }^{* * *} p<0.001$. Error bars indicate SEM. 


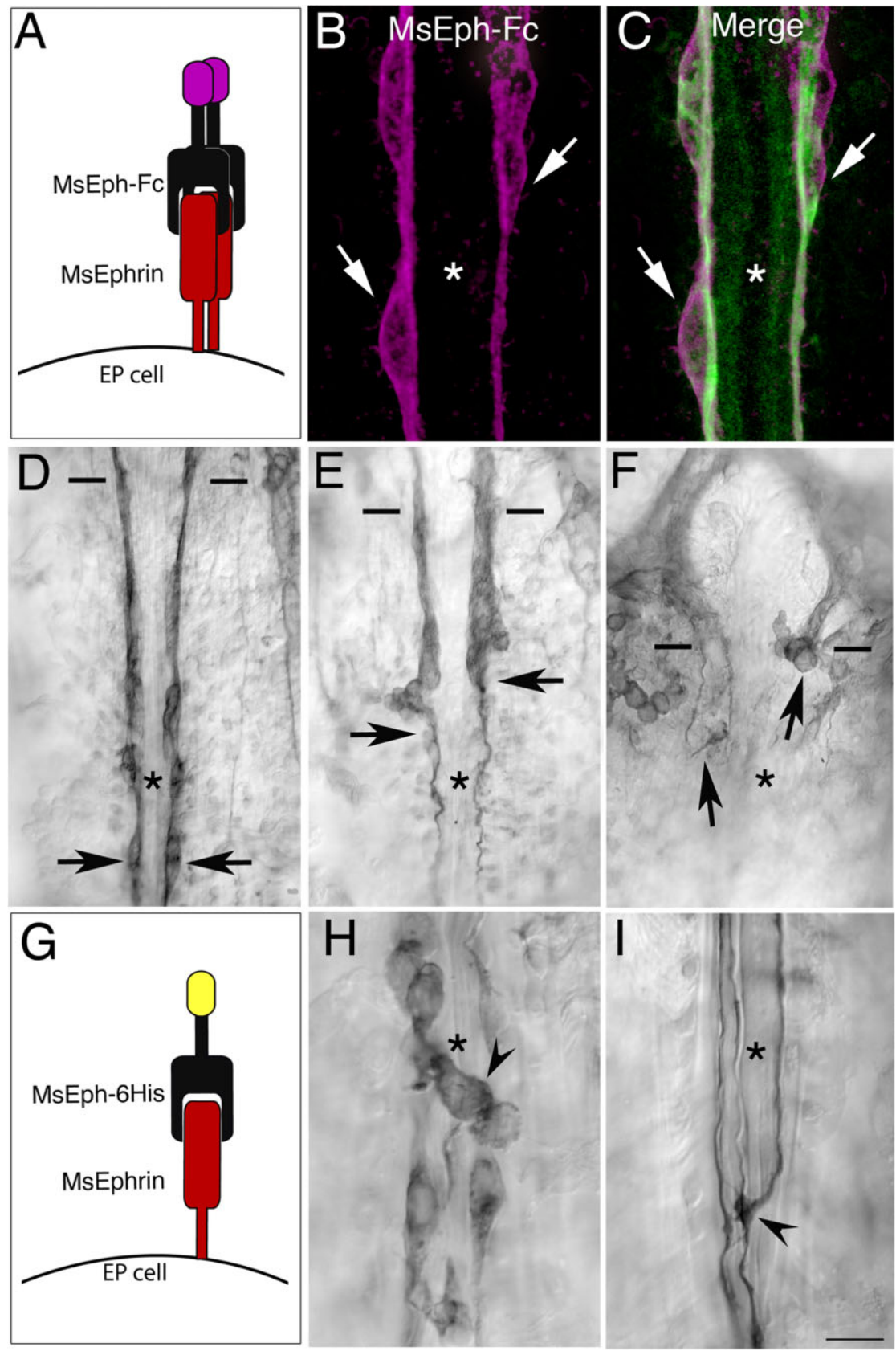

Figure 5. Dimeric MsEph-Fc proteins inhibited EP cell migration and outgrowth, whereas monomeric MsEph-6His caused aberrant midline crossovers. $A$, Schematic diagram of the interaction between dimeric MsEph-Fc fusion proteins (black, with magenta Fctag) and MsEphrin ligands on the EP cells (red). $\boldsymbol{B}$, MsEph-Fc selectively binds to the EP cells (magenta; arrows), but not the midline cells (asterisk) when applied to the ENS of an unfixed preparation (at $4^{\circ} \mathrm{C}$; detected with anti-Fc antibodies). $\boldsymbol{C}$, Counterstaining the same preparation with anti-MsFas II antibodies (green) shows that MsEph-Fc labels the EP cells (arrows) but not the muscle band pathways. $\mathbf{D}-\boldsymbol{F}$, Embryos that were treated with $\mathrm{Fc}$ proteins for $24 \mathrm{~h}$ in culture, then immunostained with anti-MsFas II to reveal the EP cells and their processes. D, Embryo that was treated with control Fc protein; the EP cells (arrows) and their processes traveled normal distances along their muscle band pathways without crossing onto the midline cells (asterisk). $\boldsymbol{E}$, Embryo treated with $20 \mu \mathrm{g} / \mathrm{ml} \mathrm{MsEph-Fc} \mathrm{showed} \mathrm{reduced} \mathrm{EP} \mathrm{cell} \mathrm{migration} \mathrm{and} \mathrm{outgrowth.} F$, Embryo treated with $50 \mu \mathrm{g} / \mathrm{ml}$ MsEph-Fc showed a more severe inhibition of migration and outgrowth. $G$, Schematic diagram of the interaction between monomeric MsEph-6His fusion proteins (black, with yellow 6 His tag) and MsEphrin ligands on the EP cells (red). $\boldsymbol{H}, \boldsymbol{I}$, Embryos that were treated with MsEph-6His showed ectopic midline crossing by the migratory EP cells $(\boldsymbol{H}$, arrowhead) and their processes $(\boldsymbol{I}$, arrowhead) that were similar to crossover phenotypes caused by MsEphrin-Fc and MsEphrin-6His. Horizontal black bars in D-F indicate the foregut-midgut boundary; asterisks in all preparations indicate the midline. Scale bar: $B, C, H, I, 20 \mu \mathrm{m} ; D-F, 50 \mu \mathrm{m}$.

teins on EP cell motility might be the result of a paradoxical response caused by blocking endogenous MsEphrin-MsEph interactions, although our foregoing experiments would predict that such an effect would only cause midline crossing. Alterna- tively, treatment with MsEph-Fc might overstimulate a reverse signaling event through MsEphrin on the neurons. To discriminate between these possibilities, we designed an MsEph-6His fusion protein (Fig. 5G) that should not form spontaneous dimers or activate reverse signaling through MsEphrin (cf. Davis et al., 1994). As shown in Figure 2 (lanes 7, 8), MsEph$6 \mathrm{His}$ did indeed behave as a monomer in both reducing and nonreducing conditions, migrating near its predicted molecular size of $62 \mathrm{kDa}$. The slightly smaller size of $\sim 57 \mathrm{kDa}$ seen in nonreducing conditions was presumably caused by incomplete denaturation of the protein.

When we treated the migratory EP cells with MsEph-6His, we observed numerous midline crossing events by both the neurons (Fig. $5 H$ ) and their processes $(I)$, at frequencies that were comparable with the effects of both MsEphrin-Fc and MsEphrin-6His (Fig. 4A). However, monomeric MsEph-6His proteins did not affect the overall extent of EP cell migration (Fig. $4 B$ ), in marked contrast to the inhibitory effects of dimeric MsEph-Fc proteins. These results are consistent with the model that monomeric MsEph-6His proteins acted by blocking endogenous MsEphrin-MsEph receptor interactions, rather than stimulating MsEphrindependent signaling. Unexpectedly, MsEph-6His also caused an increase in axonal outgrowth along the band pathways (Fig. 4C). However, this effect only became apparent over the protracted period of axonal elongation (from 65 to $80 \%$ of development), possibly reflecting a low, chronic level of endogenous MsEphrin activation in the EP cells that normally modulates their overall motility. The fact that MsEph-6His monomers induced midlinecrossing events whereas MsEph-Fc dimers inhibited migration and outgrowth supports the hypothesis that endogenous MsEph receptors at the midline normally prevent the neurons from crossing these regions via reverse activation of their MsEphrin ligands on the EP cells.

\section{Midline MsEph receptors guide}

exploratory filopodia on motile neurons During the normal migration of the EP cells along the muscle bands, new filopodia from their leading processes continually extend onto the adjacent surfaces of the midgut. Filopodia that remain in contact with the bands (which express MsFas II) tend to become stabilized, thereby promoting growth along these pathways, while filopodia that extend onto adjacent interband regions have comparatively short lifetimes and are typically retracted (Coate et al., 2007; Copenhaver, 2007). Does the pres- 
ence of bioavailable MsEph receptors on the midline cells prevent MsEphrin-positive filopodia from entering these regions? To investigate this issue, we conducted a series of short-duration experiments using animals between 58 and $60 \%$ of development, a stage when the EP cells and their leading processes advance rapidly onto the midgut (Copenhaver and Taghert, 1989b; Copenhaver et al., 1996). After treating these preparations with the different $\mathrm{Fc}$ fusion proteins for $3 \mathrm{~h}$ in culture (at $28^{\circ} \mathrm{C}$ ), we doubleimmunostained them with anti-TM-MsFas II (to visualize the neuronal processes and underlying muscle bands) and 4E11 (to label the midline interband cells). High-resolution confocal microscopy was then used to analyze the distributions of filopodia associated with the leading processes of the EP cells.

In preparations treated with control Fc protein, only $9 \%$ of the filopodia were found in contact with the midline cells (Fig. 6A, E, arrowheads, $I$ ). In contrast, treatments with MsEphrin-Fc (targeting MsEph receptors on the midline cells) led to a significant increase $(26 \%)$ in the number of filopodia that had extended onto the midline cells and failed to retract (Fig. 6B, C, F, G, arrowheads, $I$ ), although there were no significant changes in the total number of filopodia (Fig. $6 \mathrm{~J}$ ) or average growth cone area $(K)$ associated with the leading processes. Figure 6 also illustrates the range of phenotypes that were produced by treating the ENS with MsEphrin-Fc: in some preparations, an increased number of filopodia had entered the midline without affecting the orientation of the growth cone (Fig. $6 B, F$ ), whereas in more extreme cases the entire growth cone had migrated off its normal muscle band pathway and onto the midline region (Fig. $6 C, G$ ). The opposite effect was produced by treatments with MsEph-Fc: the leading processes of the EP cells in these preparations had a more tapered appearance (Fig. 6D, $H$ ) and extended significantly fewer filopodia onto the midline, compared with controls (Fig. 6I). We also detected a small but significant reduction in the total number of filopodia per leading process (Fig. $6 J$ ), although the overall size of their growth cones was not significantly reduced (Fig. $6 \mathrm{~K}$ ). Possibly, this relatively subtle effect reflected the presence of other guidance cues in the ENS that help stabilize the leading processes, thereby preventing catastrophic growth cone collapse. Nevertheless, these results suggest that during normal ENS development, reverse signaling via MsEphrin restricts the local filopodial dynamics of the leading processes extended by the migrating EP cells, thereby preventing the neurons from growing onto the midline regions of the gut.

\section{Knock-down of MsEphrin expression in the EP cells with morpholinos leads to midline crossing}

If MsEphrin-MsEph interactions are indeed required for regulating the behavior of the EP cells at the midline, then inhibiting the expression of either protein should also lead to aberrant midline crossing by the neurons and their processes. To address this issue, we treated the ENS of cultured embryos with morpholinos specifically targeting the 5' UTR of the MsEphrin gene, using EndoPorter $(0.6 \%)$ as a delivery reagent; at this concentration, EndoPorter had no deleterious effects on embryonic development (data not shown). When we introduced CFSE-labeled control morpholinos into the developing ENS, we detected the accumulation of the morpholinos in virtually all of the EP cells (supplemental Fig. 3, available at www.jneurosci.org as supplemental material), as well as in adjacent muscle cells and other non-neural cells (as expected with this delivery system). However, the introduction of these and other control morpholinos (from 1 to 50 $\mu \mathrm{M})$ had no appreciable effects on the expression or localization of either MsEphrin or MsFas II in the neurons, nor did they affect
EP cell migration and outgrowth. As shown in Figure 7, labeling these control preparations at the end of the culture period with anti-MsEphrin antibodies revealed normal patterns of MsEphrin expression on both the somata and axons of the EP cells (compare Figs. 1, 7A,D). Likewise, control morpholinos at concentrations up to $50 \mu \mathrm{M}$ had no detectable effect on MsFas II expression (Fig. $7 \mathrm{~B}, E$ ), providing further evidence that our treatment conditions did not produce any obvious nonspecific effects on gene expression or migratory behavior by the EP cells.

In contrast, treating the developing ENS with $50 \mu \mathrm{M}$ MsEphrin-specific morpholinos caused a dramatic reduction in the level of MsEphrin expression in the EP cell somata and processes (Fig. 7G,J). As with the control morpholinos, MsEphrinspecific morpholinos had no detectable effect on MsFas II expression levels in these neurons (Fig. $7 \mathrm{H}, \mathrm{K}$ ), indicating that they did not produce generalized off-target effects on gene expression. However, the MsEphrin morpholinos did induce a dramatic increase in midline crossovers (as revealed by MsFas II immunostaining) (Fig. $7 H, I, K, L$ ), an effect that was not seen in preparations treated with control morpholinos (Fig. $7 B, C, E, F$ ). Notably, those neurons and processes that grew inappropriately across the midline expressed little or no MsEphrin (Fig. $7 G-L$, arrowheads).

To quantify the effects of these treatments on MsEphrin expression by the EP cells, we estimated the relative levels of MsEphrin-specific immunofluorescence in each preparation (detected with a Cy3-conjugated secondary antibody) by normalizing against background fluorescent levels in adjacent, MsEphrin-negative regions of the gut. As an internal control for potential nonspecific effects of the morpholinos, we simultaneously quantified the relative levels of MsFas II-specific immunofluorescence in these same regions (detected with an Alexa 488-conjugated secondary antibody), again by normalizing against background levels within each preparation. Supplemental Figures 4 and 5 (available at www.jneurosci.org as supplemental material) illustrate the methods used to determine the relative levels of MsEphrin and MsFas II immunofluorescence that were associated with the migratory neurons and their growing processes. We then used these normalized values to compare the relative effects of the morpholino treatments on MsEphrin and MsFas II expression independently.

As shown in Figure $8 A$, when we compared preparations treated with control morpholinos (black histograms) versus embryos treated with MsEphrin-specific morpholinos (gray histograms), no significant differences were detected in the relative intensity of MsFas II-associated immunofluorescence in either the somata or axons of the EP cells. [The enhanced levels of MsFas II in the axons compared with the somata reflects the developmental trafficking of this adhesion receptor to regions of active motility (Wright et al., 2000).] In contrast, the relative intensity of MsEphrin-associated immunofluorescence was dramatically reduced in preparations treated with MsEphrin morpholinos, compared with preparations treated with control morpholinos (Fig. 8 B). Relative levels of MsEphrin immunofluorescence were reduced by $>90 \%$ in the somata of the EP cells and by $45 \%$ in their axons.

Concurrent with their selective effect on MsEphrin expression, treatments with MsEphrin morpholinos (1-50 $\mu \mathrm{M})$ caused a concentration-dependent increase in midline crossing events (Fig. 8C), whereas preparations treated with control morpholinos exhibited only rare crossovers by small neurites, as seen in earlier controls (compare with Fig. 4A). Thus, knocking down MsEphrin expression produced the same crossover phenotypes 

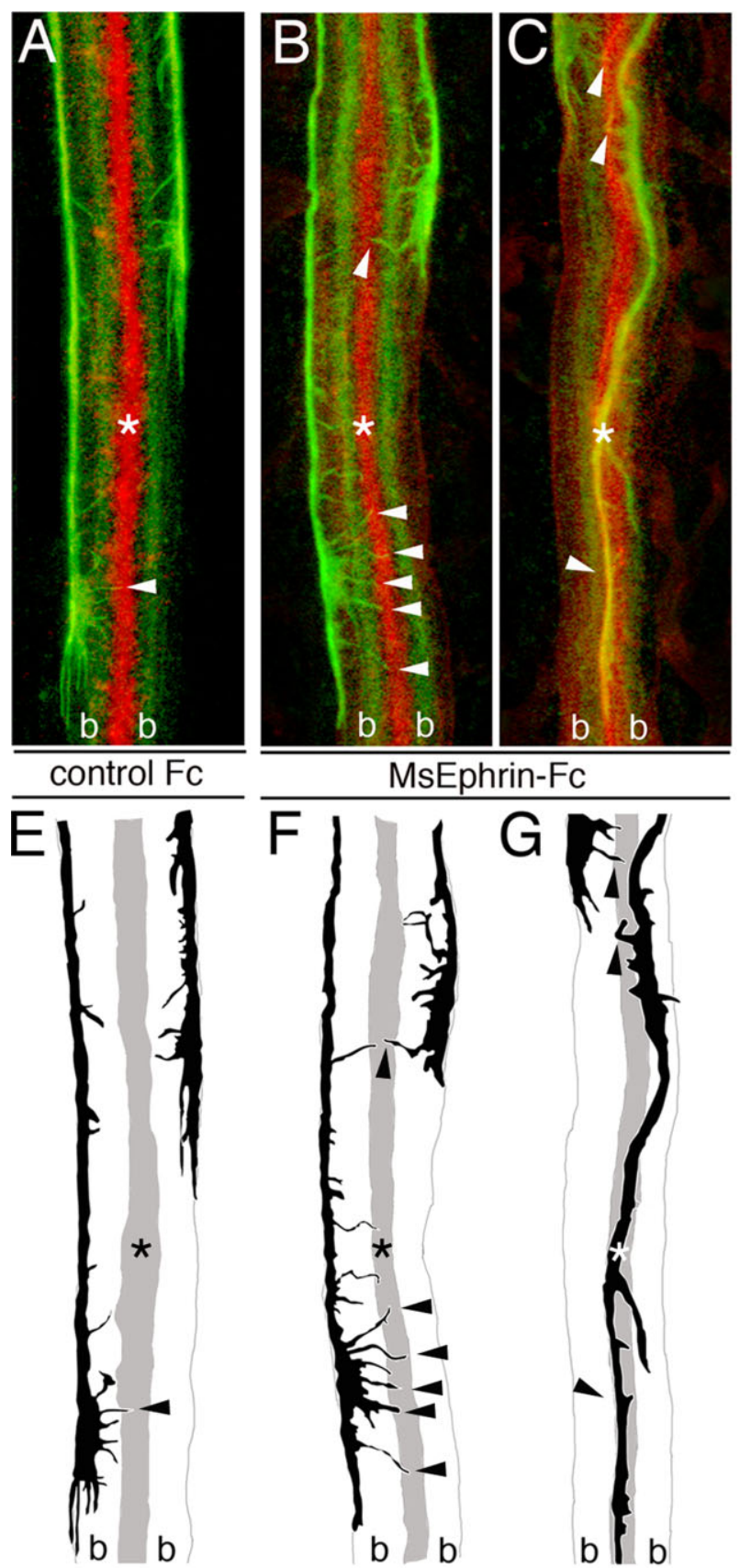

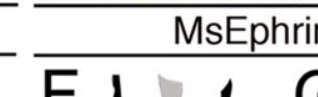

FC
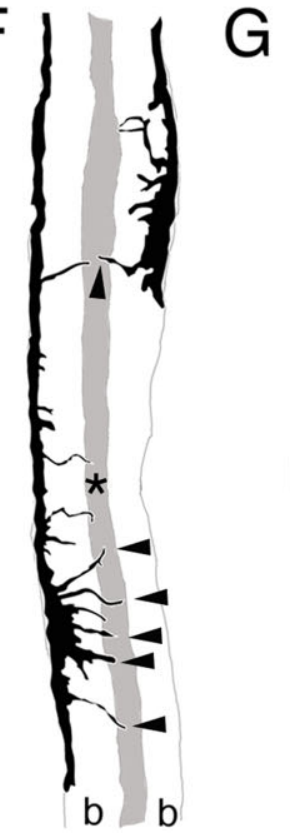

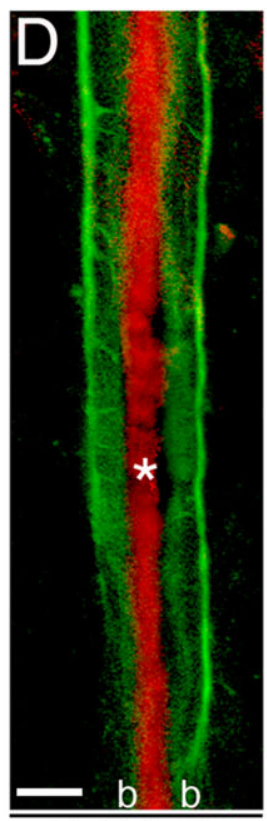

MsEph-Fc
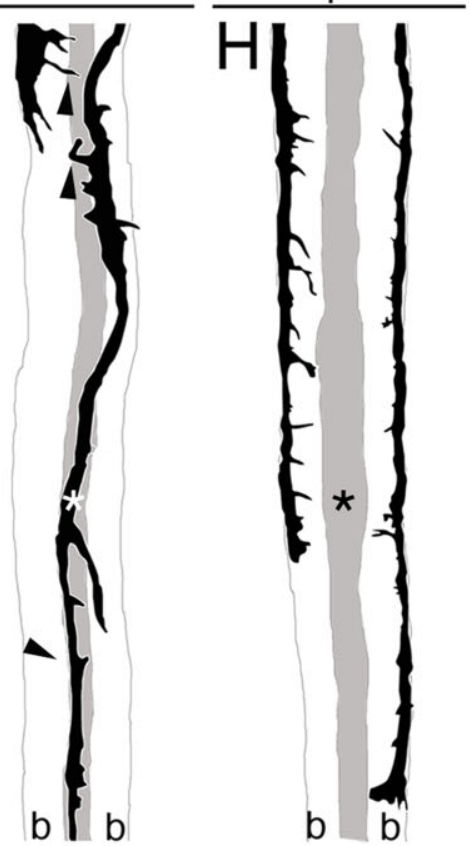
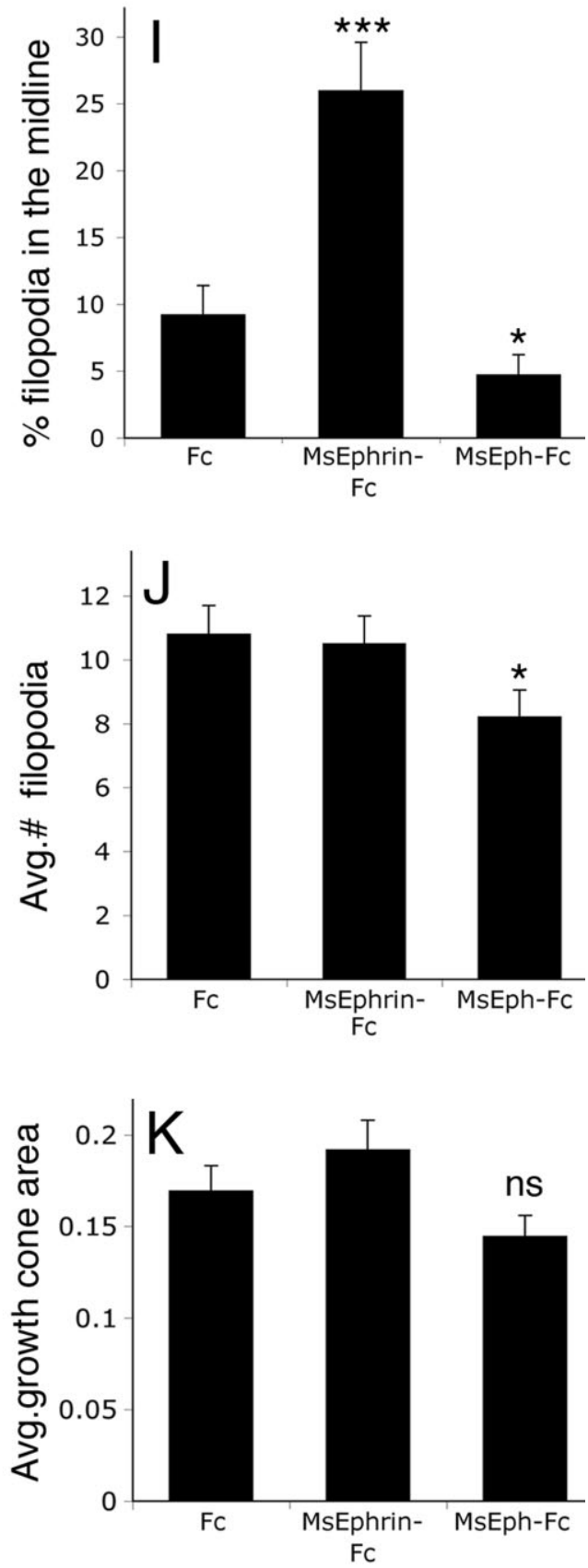

Figure 6. The effects of short-term treatments with MsEphrin-Fc and MsEph-Fc fusion proteins on the growth cones of the EP cells. Cultured embryos were treated for $3 \mathrm{~h}$ at RT with either 20 $\mu \mathrm{g} / \mathrm{ml}$ control Fc, MsEphrin-Fc, or MsEph-Fc, then fixed and stained for MsFas II (green; to label the EP cell growth cones and underlying muscle bands) and 4E11 (red; to label the midline cells). $A-D$, Representative micrographs of the different treatments. $\boldsymbol{E}-\boldsymbol{H}$, Corresponding silhouettes from $\boldsymbol{A}-\boldsymbol{D}$ used for the quantification shown in $\boldsymbol{I} \boldsymbol{K}$. Asterisks and gray stripes in $\boldsymbol{A}-\boldsymbol{H}$ indicate the position of the midline cells. $\boldsymbol{A}, \boldsymbol{E}$, Preparation treated with control Fc showed a small number of filopodia (arrowhead) that had contacted the midline (asterisk). $\boldsymbol{B}, \boldsymbol{F}$, Example of preparation treated with MsEphrin- $\mathrm{Fc}$ (targeting the midline MsEph receptors) that showed a marked increase in the number of filopodia entering the midline (arrowheads). $C, G$, Another preparation treated with MsEphrin- $\mathrm{Fc}$ in which an entire growth cone entered the midline. $\boldsymbol{D}, \boldsymbol{H}$, Embryo treated with MsEph- $\mathrm{Fc}$ (targeting MsEphrin on the EP cell growth cones) showed no detectable filopodia in contact with the midline; the total number of filopodia was also slightly reduced. II Percentage of filopodia per growth cone that had entered the midline in the different treatment groups; MsEphrin-Fc treatment resulted in significantly more filopodia that contacted the midline compared with controls, whereas MsEph-Fc treatment led to significantly fewer midline filopodia. J, Average total number of filopodia associated with the EP cell growth cones in the different treatment groups (counted within $50 \mu \mathrm{m}$ of the most distal growth cone tip). MsEph-Fc treatment resulted in significantly fewer filopodial processes per growth cone compared with controls, whereas MsEphrin-Fctreatment had no significant effect. $\boldsymbol{K}$, Average growth cone area (in arbitrary units) calculated from silhouette profiles $(\boldsymbol{E}-\boldsymbol{H})$. MsEph-Fc treatments caused a minor reduction in growth cone size, but this effect was not significant (ns). Scale bar: $\boldsymbol{A}-\boldsymbol{H}, 5 \mu \mathrm{m}$. Sample sizes for the different conditions were as follows: for $\mathrm{Fc}$ treatments, $n=12$; for MsEphrin- $\mathrm{Fc}, n=20$; for MsEph- $\mathrm{Fc}, n=18$. Significant differences in $\boldsymbol{I}-\boldsymbol{K}$ were calculated with Student's two-tailed $t$ test, ${ }^{*} p<0.05$; $* * * 0.001$. Error bars indicate SEM.

caused by blocking endogenous MsEphrin-MsEph interactions in the ENS. We also measured the effects of the morpholinos on the average total distance traveled by the EP cells along their normal muscle band pathways. As illustrated in Figure $8 D$, nei- ther the control nor MsEphrin-specific morpholinos reduced the overall extent of migration and outgrowth, just as blocking endogenous MsEphrin-MsEph interactions with our fusion constructs did not impede normal EP cell motility (compare Figs. 

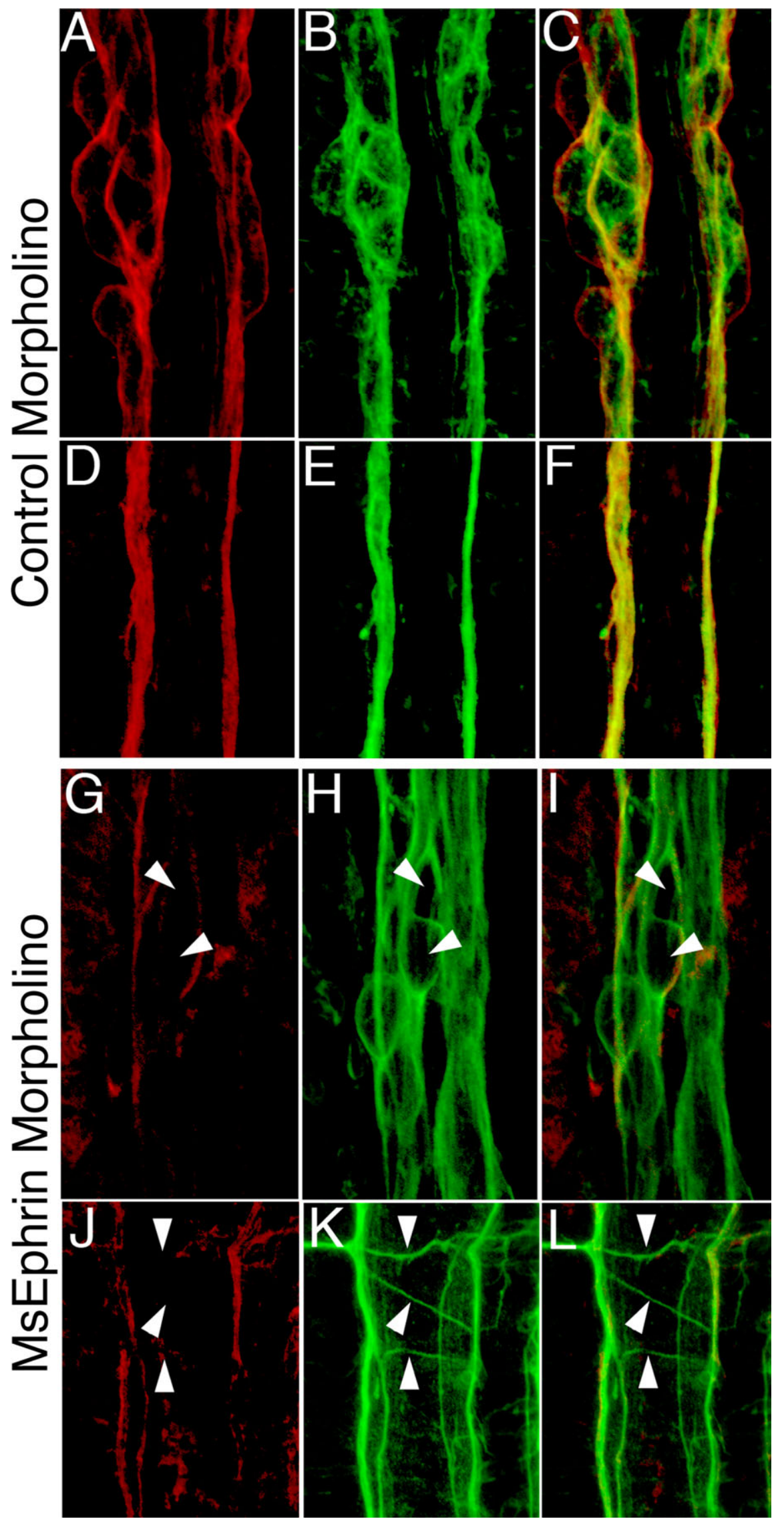

Figure 7. Knock down of MsEphrin expression using antisense morpholinos results in midline crossover phenotypes. $\boldsymbol{A}-\boldsymbol{L}$ Cultured embryos were treated with $50 \mu \mathrm{m}$ control morpholinos $(\boldsymbol{A}-\boldsymbol{F})$ or MsEphrin-specific morpholinos $(\boldsymbol{G}-\boldsymbol{L})$, then doubleimmunostained with MsEphrin antibodies (to show the residual levels of MsEphrin expression) and anti-MsFas II antibodies (to
$8 D, 4 B, C)$. In fact, at the highest concentration tested $(50 \mu \mathrm{M})$, MsEphrin morpholinos induced a slight enhancement of migration along the band pathways, increasing average migration distances by up to $25 \%$, compared with controls. This result is similar to the increase in axonal outgrowth caused by treatments with MsEph6His (Fig. 4C), again suggesting that MsEphrin-MsEph receptor interactions may modulate the overall motility of the EP cells in conjunction with preventing midline crossing. Why knocking down MsEphrin expression preferentially affected migration versus outgrowth is unclear, but may be related to our observation that the morpholino treatments depleted MsEphrin levels in the neuronal somata more efficiently than in their leading axons, where existing protein may be preferentially retained (Fig. 7G,J, supplemental Figs. 4, 5, available at www. jneurosci.org as supplemental material). The loss of MsEphrin may therefore delay the normal transition from migration to outgrowth indirectly, possibly by modulating the local cytoskeletal dynamics that distinguish these behaviors (Copenhaver, 2007). Nevertheless, these effects are in marked contrast to the strong inhibitory effects of dimeric MsEph-Fc on both migration and outgrowth.

In summary, these experiments provide evidence that MsEphrin-MsEph receptor interactions normally prevent the migratory EP cells and their processes from inappropriately crossing the midline of the developing ENS. They also support the model that reverse signaling through this GPI-linked ephrin regulates neuronal guidance within the developing ENS, an effect that we propose is mediated by the local activation of this response within the leading processes of the migrating neurons (illustrated schematically in Fig. 9). As discussed below, the integration of this reverse signaling response with input from

\section{$\leftarrow$}

reveal the full extent of EP cell migration and outgrowth, and to provide an off-target control). $\boldsymbol{A}-\boldsymbol{F}$, In preparations treated with control morpholinos, both the migratory EP cells $(\boldsymbol{A}-\boldsymbol{C})$ and their leading processes $(\boldsymbol{D}-\boldsymbol{F})$ continued to express normal levels of both MsEphrin (red) and MsFas II (green), and they showed no abnormal midline crossing. $\mathbf{G}-\boldsymbol{L}$, In preparations treated MsEphrin-specific morpholinos, both the migratory EP cells ( $\boldsymbol{G}-\boldsymbol{I})$ and their leading processes $(\boldsymbol{J}-\boldsymbol{L}$ ) exhibited a marked reduction in MsEphrin expression (red) but no detectable change in MsFas Il expression (green). In addition, an increased number of neurons and processes in these preparations (lacking MsEphrin) traveled inappropriately onto the midline (crossovers indicated by white arrowheads). Scale is the same as in Figure $6 D$. 

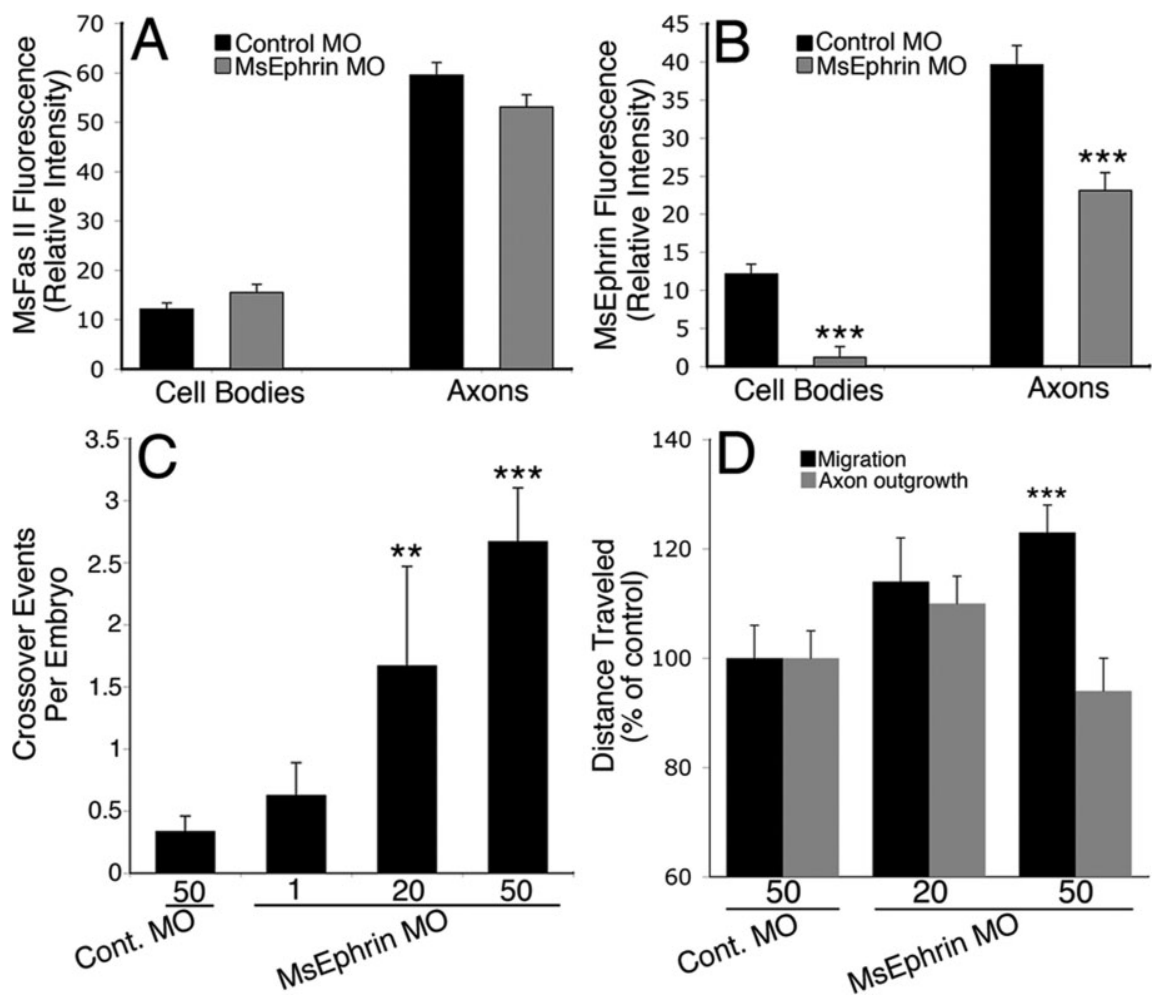

Figure 8. Quantification of the effects of morpholino treatments on MsEphrin expression and migratory behavior by the EP cells in cultured embryos. $\boldsymbol{A}$, The relative levels of MsFas II immunofluorescence in preparations treated with $50 \mu \mathrm{m}$ control morpholinos (black histograms) or MsEphrin-specific morpholinos (gray histograms) were not significantly different in either the EP cell bodies or their growing axons. MsFas II-specific immun ofluorescence was normalized to background fluorescence levels in each preparation (see Materials and Methods) (supplemental Figs. 4, 5, available at www.jneurosci.org as supplemental material). $\boldsymbol{B}$, Relative levels of MsEphrin immunofluorescence were significantly reduced in preparations treated with $50 \mu \mathrm{m}$ MsEphrin morpholinos, compared with preparations treated with control morpholinos ( $\sim 90 \%$ reduction in the EP cell bodies and $\sim 45 \%$ reduction in their distal axons). C, Treatment with different concentrations of MsEphrin-specific morpholinos (1-50 $\mu \mathrm{m})$ caused a dose-dependent increase in the number of midline crossover events (including crossovers by migrating EP cells and their growing processes), compared with preparations treated with control morpholinos. D, Quantification of the total average distance traveled by the migrating EP cells and growing axons along their muscle band pathways (normalized to untreated controls) Neither control morpholinos nor MsEphrin-specific morpholinos inhibited migration and outgrowth, but the highest concentration of MsEphrin morpholinos caused a significant increase in migration distance. Morpholino concentrations in $\boldsymbol{C}$ and $\boldsymbol{D}$ are indicated in $\mu \mathrm{m}$. Fourteen preparations were used for each treatment condition, and significant differences were calculated with Student's two-tailed $t$ test, ${ }^{* *} p<0.01 ;{ }^{* * *} p<0.001$. Error bars indicate SEM.

other attractive and repulsive cues encountered by the migratory EP cells on the midgut pathways ultimately determines the final distribution of neurons in the mature ENS.

\section{Discussion}

The establishment of midline boundaries by ephrin-Eph receptor interactions

Graded distributions of ephrins and Eph receptors help form topographic projection maps within the brain (Cheng et al., 1995; Drescher et al., 1997), but they can also be expressed in mutually exclusive patterns that define discrete domains in a variety of tissues (Krull et al., 1997; Wang and Anderson, 1997; Cooke and Moens, 2002). In many organisms, this process plays an important role in establishing midline boundaries. For example, during the formation of the vertebrate spinal cord, ephrin-B3 is expressed by cells at the ventral midline that repel commissural neurons, in part via forward signaling through $\mathrm{EphB}$ receptors (Kadison et al., 2006). Multiple EphB receptors and ephrin-B ligands similarly regulate midline crossing by axons in the corpus callosum (Mendes et al., 2006). At the same time, interactions between several EphA receptors and their ephrin-A ligands may attract a subset of callosal projections across the midline (Hu et al., 2003), although the extent to which cross talk among the different ephrin and Eph subtypes regulates neuronal guidance in this region remains poorly understood. Likewise in Caenorhabditis elegans, Eph-ephrin interactions regulate axonal guidance at the ventral midline (Zallen et al., 1999), acting in conjunction with Ig-family receptors (Boulin et al., 2006).

Our results in Manduca have revealed a new example of this general theme, whereby spatially restricted patterns of a specific ephrin ligand (MsEphrin) and its cognate Eph receptor (MsEph) help define an "enteric" midline during embryonic development. However, our data also provide strong evidence that reverse signaling through a GPI-linked ephrin is the primary mechanism by which cell-cell repulsion is regulated in this system. During normal ENS development, the EP cells migrate preferentially along the muscle band pathways of the gut (Fig. 9A), but also transiently extend processes onto the adjacent interband muscles and midline regions. When an MsEphrin-expressing filopodium from an EP cell extends onto the midline (Fig. 9B, step 1), it encounters MsEph receptors expressed by these cells (step 2), initiating a reverse signaling response via MsEphrin that results in filopodial retraction (step 3). In this manner, MsEph-MsEphrin interactions prevent inappropriate midline crossing by EP cells, maintaining the migratory neurons and their processes on the muscle band pathways.

In contrast to other preparations, where multiple ephrins and Eph receptors are often expressed in overlapping patterns by the same cells (Frisen et al., 1999; Klein, 2001; Konstantinova et al., 2007), MsEphrin and MsEph are expressed in a strictly complementary pattern within the developing ENS: MsEphrin is only expressed by the migratory EP cells, whereas MsEph is exclusively expressed by the midline muscle cells (Fig. 1). Consistent with these expression patterns, MsEphrin fusion proteins bind specifically to the MsEphexpressing midline cells, whereas MsEph fusion proteins only label the MsEphrin-positive neurons (Figs. 3, 5) (Coate et al., 2007). Furthermore, the results of our manipulations in embryo culture suggest that reverse signaling via MsEphrin controls the behavior of the enteric neurons (summarized in supplemental Fig. 6, available at www.jneurosci.org as supplemental material). First, targeting endogenous MsEph receptors on the midline cells with either monomeric MsEphrin-6His (supplemental Fig. 6A, available at www.jneurosci.org as supplemental material) or dimeric MsEphrin-Fc (supplemental Fig. 6B, available at www. jneurosci.org as supplemental material) caused ectopic midline crossing by the EP cells, consistent with the model that both of these fusion proteins blocked endogenous MsEphrin-MsEph interactions, thereby permitting the neurons to grow inappropri- 
ately across the midline. A similar crossover phenotype was produced by targeting MsEphrin on the neurons with monomeric MsEph-6His (supplemental Fig. 6C, available at www.jneurosci.org as supplemental material), a construct that should bind endogenous ligands without inducing reverse signaling (cf. Davis et al., 1994). Third, knocking down MsEphrin expression in the EP cells with morpholinos also induced ectopic crossovers without inhibiting migration or outgrowth (supplemental Fig. $6 D$, available at www.jneurosci.org as supplemental material). Together, these results indicate that bioavailable MsEphrin ligands and MsEph receptors must both be present in the developing ENS to regulate the normal behavior of the migratory neurons at the midline.

In contrast to the foregoing experiments, treating the EP cells with dimeric MsEph-Fc constructs caused a significant inhibition of migration and outgrowth, as well as preventing midline crossing (Figs. 4, 5, supplemental Fig. 2, available at www.jneurosci.org as supplemental material). In short-term cultures, we found that MsEphrin-Fc treatments increased the number of filopodia extending from the leading processes of the neurons onto the midline (Fig. $6 F, G, I$ ), whereas MsEph-Fc caused a general reduction in filopodial number (Fig. $6 H, J)$. Based on these findings, we propose that reverse signaling from MsEph receptors through MsEphrin on the migratory neurons normally prevents their leading processes from growing onto the midline regions, whereas hyperactivation of this signaling response (with dimeric MsEph-Fc) causes a general inhibition of their cell motility (supplemental Fig. $6 E$, available at www.jneurosci.org as supplemental material).

Given these results, we were surprised that our short-term treatments with MsEph-Fc did not induce more dramatic changes in growth cone shape (Fig. $6 \mathrm{~K}$ ). Only when we applied MsEph-Fc at the onset of migration did we observe a global effect on EP cell motility, akin to the phenomenon of growth cone collapse in vitro (Harbott and Nobes, 2005; Evans et al., 2007). One explanation for this difference is that within the developing ENS, the EP cells may be most sensitive to MsEphrin-dependent signaling during their initial stages of migration, when each neuron extends a wide array of exploratory filopodia before aligning with a particular band pathway (Copenhaver et al., 1996; Wright et al., 1999). Alternatively, additional guidance cues on the muscle bands (including MsFas II) may help stabilize the EP cells once they have begun to migrate, at which time MsEph-Fc dimers may only inhibit their leading processes without causing outright collapse.

Previous studies in cell culture have shown that MsEphrin-Fc constructs are also capable of activating forward signaling via MsEph receptors (Kaneko and Nighorn, 2003), consistent with the induction of forward signaling by ephrins in vertebrates (Davy and Soriano, 2005; Konstantinova et al., 2007). An alternative explanation for our data might therefore involve a forward signaling response from MsEphrin on the EP cells via MsEph receptors on the midline cells, which in turn could induce a secondary feedback signal that causes filopodial retraction. How- ever, by this scenario, applying MsEphrin-Fc complexes (targeting MsEph receptors at the midline) should hyperactivate this feedback signaling event, resulting in excessive filopodial retraction and a general inhibition of neuronal motility. Instead, these treatments induced the opposite effect, resulting in inappropriate midline crossing by both the neurons and their processes. Thus, simply occupying the ligand-binding sites of endogenous MsEph receptors with either monomeric (MsEphrin-6His) or dimeric constructs (MsEphrin-Fc) was apparently sufficient to induce ectopic midline crossing, regardless of MsEph receptor activation. Forward signaling through MsEph receptors might possibly regulate some later aspect of ENS development, although complete removal of the EP cells before migration produces no obvious defects in midgut differentiation (Copenhaver et al., 1996). Therefore, our results support a role for reverse signaling, but not forward signaling via MsEphrin in the control of neuronal migration at the enteric midline.

\section{An integrated response to multiple guidance cues regulates neuronal migration in the ENS}

Previously, we showed that disrupting MsFas II-dependent interactions between the neurons and the muscle bands impeded their migration and outgrowth, indicating that this homophilic receptor promotes neuronal motility within the developing ENS (Copenhaver et al., 1996; Wright et al., 1999). However, these manipulations did not induce ectopic growth onto the midline or the lateral interband regions, indicating the presence of other cues that restrict the EP cells from these nonpathway domains (Wright et al., 1999; Copenhaver, 2007). Our current results indicate that MsEph receptors on the midline cells represent one of these inhibitory cues, signaling via MsEphrin on the neurons to prevent ectopic midline crossing. Intriguingly, both MsEphrin and MsFas II can be detected within the same populations of exploratory filopodia (Fig. 1) (Coate et al., 2007), suggesting that 
the net effects of attractive and repulsive guidance cues on local filopodial dynamics may ultimately determine the pathway chosen by each migratory neuron.

How might reverse signaling via MsEphrin modulate the behavior of migratory neurons, given that it is a GPI-linked ligand? Reverse signaling through type-B (transmembrane) ephrins can be mediated via the activation of SFKs (Palmer et al., 2002), modulation of heterotrimeric G-proteins (Lu et al., 2001), or recruitment of other adapter and signaling molecules (Kullander and Klein, 2002). Reverse signaling via type-A (GPI-linked) ephrins has remained more enigmatic, although examples of this process have now been implicated in the formation of retinotectal topographic maps (Knoll and Drescher, 2002) and the control of neurogenesis (Holmberg et al., 2005). Studies in cell culture have also indicated that reverse signaling by A-type ephrins may also involve the activation of nonreceptor tyrosine kinases, which in turn can regulate integrin-dependent adhesion (Davy et al., 1999; Huai and Drescher, 2001). By exploiting the accessibility of the developing ENS in Manduca, we can now investigate the mechanisms by which reverse signaling via a specific GPI-linked ephrin (MsEphrin) regulates cellular motility in vivo, and how these signaling events are integrated with input from other guidance cues to direct neuronal migration within the developing embryo.

\section{References}

Bossing T, Brand AH (2002) Dephrin, a transmembrane ephrin with a unique structure, prevents interneuronal axons from exiting the Drosophila embryonic CNS. Development 129:4205-4218.

Boulin T, Pocock R, Hobert O (2006) A novel Eph receptor-interacting IgSF protein provides C. elegans motoneurons with midline guidepost function. Curr Biol 16:1871-1883.

Cheng HJ, Nakamoto M, Bergemann AD, Flanagan JG (1995) Complementary gradients in expression and binding of ELF-1 and Mek4 in development of the topographic retinotectal projection map. Cell 82:371-381.

Chrencik JE, Brooun A, Recht MI, Kraus ML, Koolpe M, Kolatkar AR, Bruce RH, Martiny-Baron G, Widmer H, Pasquale EB, Kuhn P (2006) Structure and thermodynamic characterization of the EphB4/Ephrin-B2 antagonist peptide complex reveals the determinants for receptor specificity. Structure 14:321-330.

Coate TM, Swanson TL, Proctor TM, Nighorn AJ, Copenhaver PF (2007) Eph receptor expression defines midline boundaries for ephrin-positive migratory neurons in the enteric nervous system of Manduca sexta. J Comp Neurol 502:175-191.

Contractor A, Rogers C, Maron C, Henkemeyer M, Swanson GT, Heinemann SF (2002) Trans-synaptic Eph receptor-ephrin signaling in hippocampal mossy fiber LTP. Science 296:1864-1869.

Cooke JE, Moens CB (2002) Boundary formation in the hindbrain: Eph only it were simple. Trends Neurosci 25:260-267.

Copenhaver PF (2007) How to innervate a simple gut: familiar themes and unique aspects in the formation of the insect enteric nervous system. Dev Dyn 236:1841-1864.

Copenhaver PF, Taghert PH (1989a) Development of the enteric nervous system in the moth I. Diversity of cell types and the embryonic expression of FMRFamide-related neuropeptides. Dev Biol 131:70-84.

Copenhaver PF, Taghert PH (1989b) Development of the enteric nervous system in the moth. II. Stereotyped cell migration precedes the differentiation of embryonic neurons. Dev Biol 131:85-101.

Copenhaver PF, Taghert PH (1990) Neurogenesis in the insect enteric nervous system: generation of premigratory neurons from an epithelial placode. Development 109:17-28.

Copenhaver PF, Horgan AM, Combes S (1996) An identified set of visceral muscle bands is essential for the guidance of migratory neurons in the enteric nervous system of Manduca sexta. Dev Biol 179:412-426.

Cowan CA, Henkemeyer M (2001) The SH2/SH3 adaptor Grb4 transduces B-ephrin reverse signals. Nature 413:174-179.

Dalva MB, Takasu MA, Lin MZ, Shamah SM, Hu L, Gale NW, Greenberg ME (2000) EphB receptors interact with NMDA receptors and regulate excitatory synapse formation. Cell 103:945-956.

Davis S, Gale NW, Aldrich TH, Maisonpierre PC, Lhotak V, Pawson T, Gold- farb M, Yancopoulos GD (1994) Ligands for EPH-related receptor tyrosine kinases that require membrane attachment or clustering for activity. Science 266:816-819.

Davy A, Soriano P (2005) Ephrin signaling in vivo: look both ways. Dev Dyn 232:1-10.

Davy A, Gale NW, Murray EW, Klinghoffer RA, Soriano P, Feuerstein C, Robbins SM (1999) Compartmentalized signaling by GPI-anchored ephrin-A5 requires the Fyn tyrosine kinase to regulate cellular adhesion. Genes Dev 13:3125-3135.

Dearborn Jr R, He Q, Kunes S, Dai Y (2002) Eph receptor tyrosine kinasemediated formation of a topographic map in the Drosophila visual system. J Neurosci 22:1338-1349.

Drescher U, Kremoser C, Handwerker C, Loschinger J, Noda M, Bonhoeffer F (1995) In vitro guidance of retinal ganglion cell axons by RAGS, a 25 $\mathrm{kDa}$ tectal protein related to ligands for Eph receptor tyrosine kinases. Cell 82:359-370.

Drescher U, Bonhoeffer F, Muller BK (1997) The Eph family in retinal axon guidance. Curr Opin Neurobiol 7:75-80.

Evans IR, Renne T, Gertler FB, Nobes CD (2007) Ena/VASP proteins mediate repulsion from ephrin ligands. J Cell Sci 120:289-298.

Frank S, Kammerer RA, Mechling D, Schulthess T, Landwehr R, Bann J, Guo Y, Lustig A, Bachinger HP, Engel J (2001) Stabilization of short collagen-like triple helices by protein engineering. J Mol Biol 308:1081-1089.

Frisen J, Holmberg J, Barbacid M (1999) Ephrins and their Eph receptors: multitalented directors of embryonic development. EMBO J 18:5159-5165.

Fu WY, Chen Y, Sahin M, Zhao XS, Shi L, Bikoff JB, Lai KO, Yung WH, Fu AK, Greenberg ME, Ip NY (2007) Cdk5 regulates EphA4-mediated dendritic spine retraction through an ephexin1-dependent mechanism. Nat Neurosci 10:67-76.

Grenningloh G, Rehm EJ, Goodman CS (1991) Genetic analysis of growth cone guidance in Drosophila: fasciclin II functions as a neuronal recognition molecule. Cell 67:45-57.

Hamlin JA, Fang H, Schwob JE (2004) Differential expression of the mammalian homologue of fasciclin II during olfactory development in vivo and in vitro. J Comp Neurol 474:438-452.

Harbott LK, Nobes CD (2005) A key role for Abl family kinases in EphA receptor-mediated growth cone collapse. Mol Cell Neurosci 30:1-11.

Hattori M, Osterfield M, Flanagan JG (2000) Regulated cleavage of a contact-mediated axon repellent. Science 289:1360-1365.

Himanen JP, Rajashankar KR, Lackmann M, Cowan CA, Henkemeyer M, Nikolov DB (2001) Crystal structure of an Eph receptor-ephrin complex. Nature 414:933-938.

Himanen JP, Chumley MJ, Lackmann M, Li C, Barton WA, Jeffrey PD, Vearing C, Geleick D, Feldheim DA, Boyd AW, Henkemeyer M, Nikolov DB (2004) Repelling class discrimination: ephrin-A5 binds to and activates EphB2 receptor signaling. Nat Neurosci 7:501-509.

Holmberg J, Armulik A, Senti KA, Edoff K, Spalding K, Momma S, Cassidy R, Flanagan JG, Frisen J (2005) Ephrin-A2 reverse signaling negatively regulates neural progenitor proliferation and neurogenesis. Genes Dev 19:462-471.

Horgan AM, Copenhaver PF (1998) G protein-mediated inhibition of neuronal migration requires calcium influx. J Neurosci 18:4189-4200.

Horgan AM, Lagrange MT, Copenhaver PF (1995) A developmental role for the heterotrimeric $\mathrm{G}$ protein Go alpha in a migratory population of embryonic neurons. Dev Biol 172:640-653.

Hu Z, Yue X, Shi G, Yue Y, Crockett DP, Blair-Flynn J, Reuhl K, Tessarollo L, Zhou R (2003) Corpus callosum deficiency in transgenic mice expressing a truncated ephrin-A receptor. J Neurosci 23:10963-10970.

Huai J, Drescher U (2001) An ephrin-A-dependent signaling pathway controls integrin function and is linked to the tyrosine phosphorylation of a 120-kDa protein. J Biol Chem 276:6689-6694.

Kadison SR, Makinen T, Klein R, Henkemeyer M, Kaprielian Z (2006) EphB receptors and ephrin- $\mathrm{B} 3$ regulate axon guidance at the ventral midline of the embryonic mouse spinal cord. J Neurosci 26:8909-8914.

Kaneko M, Nighorn A (2003) Interaxonal Eph-ephrin signaling may mediate sorting of olfactory sensory axons in Manduca sexta. J Neurosci 23:11523-11538.

Kasemeier-Kulesa JC, Bradley R, Pasquale EB, Lefcort F, Kulesa PM (2006) Eph/ephrins and N-cadherin coordinate to control the pattern of sympathetic ganglia. Development 133:4839-4847. 
Klein R (2001) Excitatory Eph receptors and adhesive ephrin ligands. Curr Opin Cell Biol 13:196-203.

Knoll B, Drescher U (2002) Ephrin-As as receptors in topographic projections. Trends Neurosci 25:145-149.

Kobayashi N, Kostka G, Garbe JH, Keene DR, Bachinger HP, Hanisch FG, Markova D, Tsuda T, Timpl R, Chu ML, Sasaki T (2007) A comparative analysis of the fibulin protein family. Biochemical characterization, binding interactions, and tissue localization. J Biol Chem 282:11805-11816.

Konstantinova I, Nikolova G, Ohara-Imaizumi M, Meda P, Kucera T, Zarbalis K, Wurst W, Nagamatsu S, Lammert E (2007) EphA-Ephrin-Amediated beta cell communication regulates insulin secretion from pancreatic islets. Cell 129:359-370.

Krull CE, Lansford R, Gale NW, Collazo A, Marcelle C, Yancopoulos GD, Fraser SE, Bronner-Fraser M (1997) Interactions of Eph-related receptors and ligands confer rostrocaudal pattern to trunk neural crest migration. Curr Biol 7:571-580.

Kullander K, Klein R (2002) Mechanisms and functions of Eph and ephrin signalling. Nat Rev Mol Cell Biol 3:475-486.

Laemmli UK (1970) Cleavage of structural proteins during the assembly of the head of bacteriophage T4. Nature 227:680-685.

Lu Q, Sun EE, Klein RS, Flanagan JG (2001) Ephrin-B reverse signaling is mediated by a novel PDZ-RGS protein and selectively inhibits $\mathrm{G}$ proteincoupled chemoattraction. Cell 105:69-79.

Mendes SW, Henkemeyer M, Liebl DJ (2006) Multiple Eph receptors and B-class ephrins regulate midline crossing of corpus callosum fibers in the developing mouse forebrain. J Neurosci 26:882-892.

Mohamed AM, Chin-Sang ID (2006) Characterization of loss-of-function and gain-of-function Eph receptor tyrosine kinase signaling in C. elegans axon targeting and cell migration. Dev Biol 290:164-176.

Murai KK, Pasquale EB (2003) 'Eph'ective signaling: forward, reverse and crosstalk. J Cell Sci 116:2823-2832.

Pabbisetty KB, Yue X, Li C, Himanen JP, Zhou R, Nikolov DB, Hu L (2007) Kinetic analysis of the binding of monomeric and dimeric ephrins to Eph receptors: correlation to function in a growth cone collapse assay. Protein Sci 16:355-361.

Palmer A, Klein R (2003) Multiple roles of ephrins in morphogenesis, neuronal networking, and brain function. Genes Dev 17:1429-1450.

Palmer A, Zimmer M, Erdmann KS, Eulenburg V, Porthin A, Heumann R, Deutsch U, Klein R (2002) EphrinB phosphorylation and reverse signaling: regulation by Src kinases and PTP-BL phosphatase. Mol Cell 9:725-737.

Pasquale EB (2005) Eph receptor signalling casts a wide net on cell behaviour. Nat Rev Mol Cell Biol 6:462-475.
Poliakov A, Cotrina M, Wilkinson DG (2004) Diverse roles of eph receptors and ephrins in the regulation of cell migration and tissue assembly. Dev Cell 7:465-480.

Santiago A, Erickson CA (2002) Ephrin-B ligands play a dual role in the control of neural crest cell migration. Development 129:3621-3632.

Segura I, Essmann CL, Weinges S, Acker-Palmer A (2007) Grb4 and GIT1 transduce ephrinB reverse signals modulating spine morphogenesis and synapse formation. Nat Neurosci 10:301-310.

Stein E, Lane AA, Cerretti DP, Schoecklmann HO, Schroff AD, Van Etten RL, Daniel TO (1998) Eph receptors discriminate specific ligand oligomers to determine alternative signaling complexes, attachment, and assembly responses. Genes Dev 12:667-678.

St. John JA, Tisay KT, Caras IW, Key B (2000) Expression of EphA5 during development of the olfactory nerve pathway in rat. J Comp Neurol 416: $540-550$.

Summerton JE (2005) Endo-Porter: a novel reagent for safe, effective delivery of substances into cells. Ann NY Acad Sci 1058:62-75.

Takemoto M, Fukuda T, Sonoda R, Murakami F, Tanaka H, Yamamoto N (2002) Ephrin-B3-EphA4 interactions regulate the growth of specific thalamocortical axon populations in vitro. Eur J Neurosci 16:1168-1172.

van Holde KE (1985) Physical biochemistry. Chaps 4, 5, Ed 2, pp 91-136. Englewood Cliffs, NJ: Prentice Hall.

Vidovic M, Nighorn A, Koblar S, Maleszka R (2007) Eph receptor and ephrin signaling in developing and adult brain of the honeybee (Apis mellifera). Dev Neurobiol 67:233-251.

Wang HU, Anderson DJ (1997) Eph family transmembrane ligands can mediate repulsive guidance of trunk neural crest migration and motor axon outgrowth. Neuron 18:383-396.

Wilkinson DG (2001) Multiple roles of EPH receptors and ephrins in neural development. Nat Rev Neurosci 2:155-164.

Wright JW, Copenhaver PF (2000) Different isoforms of fasciclin II play distinct roles in the guidance of neuronal migration during insect embryogenesis. Dev Biol 225:59-78.

Wright JW, Schwinof KM, Snyder MA, Copenhaver PF (1998) A delayed role for nitric oxide-sensitive guanylate cyclases in a migratory population of embryonic neurons. Dev Biol 204:15-33.

Wright JW, Snyder MA, Schwinof KM, Combes S, Copenhaver PF (1999) A role for fasciclin II in the guidance of neuronal migration. Development 126:3217-3228.

Zallen JA, Kirch SA, Bargmann CI (1999) Genes required for axon pathfinding and extension in the C. elegans nerve ring. Development 126:36793692. 